\title{
Investigations of the Southeast Gateway at Mission San Jose, Bexar County, Texas
}

Cynthia L. Tennis

Center for Archaeological Research

Follow this and additional works at: https://scholarworks.sfasu.edu/ita

Part of the American Material Culture Commons, Archaeological Anthropology Commons, Environmental Studies Commons, Other American Studies Commons, Other Arts and Humanities Commons, Other History of Art, Architecture, and Archaeology Commons, and the United States History Commons

Tell us how this article helped you.

This Article is brought to you for free and open access by the Center for Regional Heritage Research at SFA ScholarWorks. It has been accepted for inclusion in Index of Texas Archaeology: Open Access Gray Literature from the Lone Star State by an authorized editor of SFA ScholarWorks. For more information, please contact cdsscholarworks@sfasu.edu. 
Investigations of the Southeast Gateway at Mission San Jose, Bexar County, Texas

\section{Creative Commons License}

\section{(c) (i) (8)}

This work is licensed under a Creative Commons Attribution-NonCommercial 4.0 International License 


\title{
Investigations of the Southeast Gateway at Mission San José, Bexar County, Texas
}

\author{
Cynthia L. Tennis
}

\author{
with contributions by \\ Johanna Hunziker and Barbara A. Meissner
}

Robert J. Hard, Principal Investigator

Texas Antiquities Permit No. 1649

Ccopyright

Center for Archaeological Research

The University of Texas at San Antonio

Archaeological Survey Report, No. 252 
The following information is provided in accordance with the General Rules of Practice and Procedure, Chapter 41.11 (Investigative Reports), Texas Antiquities Committee:

1. Type of investigation: Mitigation

2. Project name: San José Southeast Gateway

3. County: Bexar

4. Principal investigator: Robert J. Hard

5. Name and location of sponsoring agency: San Antonio Missions National Historical Park, San Antonio, Texas

6. Texas Antiquities Committee Permit No.: 1649

7. Published by the Center for Archaeological Research, The University of Texas at San Antonio, 6900 N. Loop 1604 W., San Antonio, Texas 78249-0658, 1998

A list of publications offered by the Center for Archaeological Research is available. Call (210) 458-4378; write to the Center for Archaeological Research, The University of Texas at San Antonio, 6900 N. Loop 1604 W., San Antonio, Texas 78249-0658; e-mail to car@lonestar.utsa.edu; or visit CAR’s Web site at http://www.csbs.utsa.edu/ research/car/index.htm. 


\begin{abstract}
In April 1996, the Center for Archaeological Research (CAR) of The University of Texas at San Antonio (UTSA) conducted archaeological investigations in the vicinity of the southeast gate at Mission San José y San Miguel de Aguayo, 41BX3. This investigation was necessitated by final-stage improvements associated with the construction of the National Park Service Visitors' Center which included the installation of a storm drain to channel rain water away from the mission compound. The drain was scheduled to run from a point $22 \mathrm{ft}$ inside the mission compound, through the southeast gateway, and to connect with an existing drainage system $100 \mathrm{ft}$ southeast of the gate. During previous archaeological testing conducted by CAR in 1993 in anticipation of the construction of the visitors' center (Hard et al. 1995), an undisturbed Colonial-period deposit was identified 15-20 inches below the surface along segments of the proposed 36-inch-wide storm drain impact area. A stone alignment believed to represent a portion of the original mission wall and Spanish colonial-period artifacts were identified in a zone $25-35$ inches below the surface within the southeast gateway.

Based on this information, the present data recovery project was designed. Nine 4-x-4-ft units and one 6-x-6-ft unit were excavated along the expanse of the drainage trench within the compound and gateway proper. Nine shovel tests and three backhoe trenches were also dug along the portion of the proposed pipeline outside the mission walls where previous investigations revealed the presence of post-1900 activities (Hard et al. 1995). This work resulted in the recovery of ceramics, lithics, and faunal remains from relatively undisturbed Spanish colonial context as well as cultural material from nineteenth- and twentieth-century occupations. During excavation, portions of the original exterior and interior walls of the mission compound were discovered. Construction plans were altered to preserve these exposed sections of the wall.
\end{abstract}




\section{Contents}

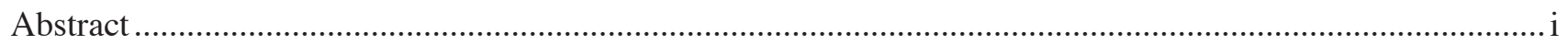

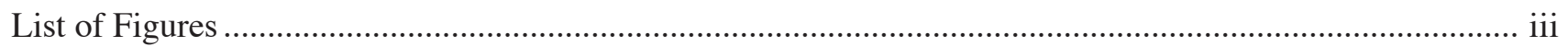

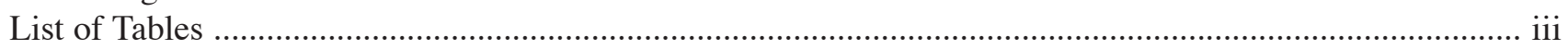

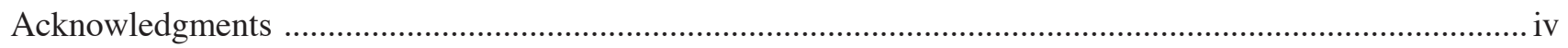

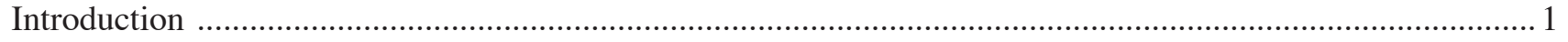

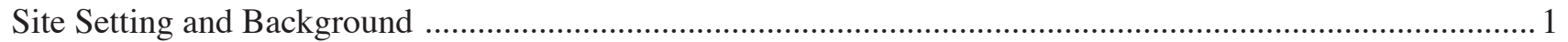

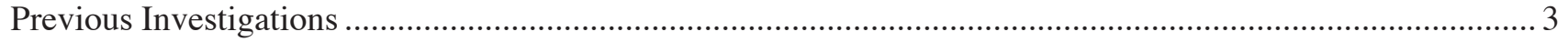

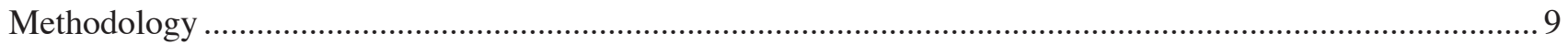

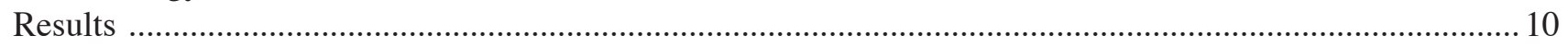

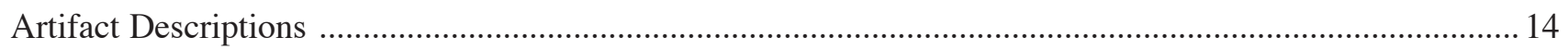

Lithics

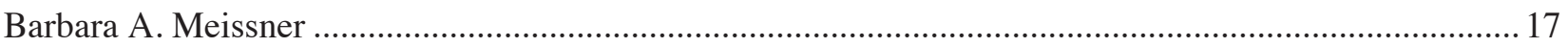

Faunal Analysis

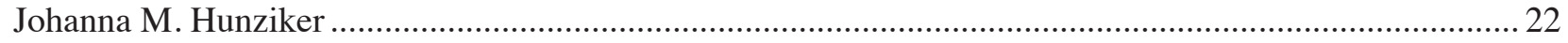

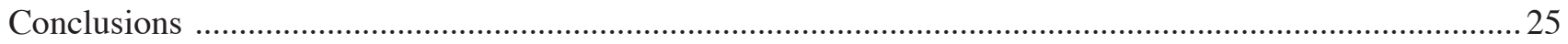

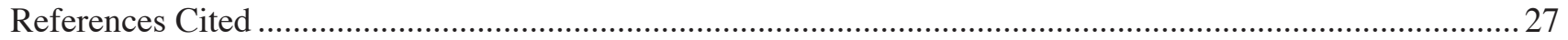




\section{Figures}

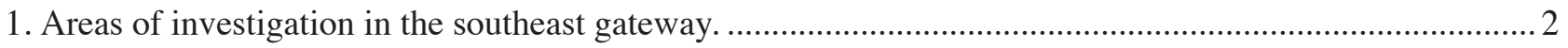

2. Aerial photograph of Mission San José, ca. 1920, prior to reconstruction. ............................................... 4

3. Aerial photograph of Mission San José, ca. 1935, during reconstruction. ..................................................5

4. Early location of New Road through Mission San José. .................................................................. 6

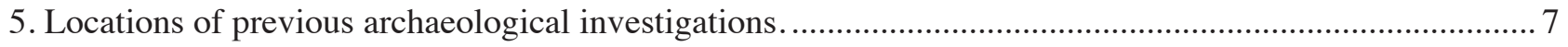

6. Areas of 1993 CAR archaeological investigations with details of Area B excavations. ........................... 8

7. Layout of 1996 excavation units within southeast gateway. ................................................................ 9

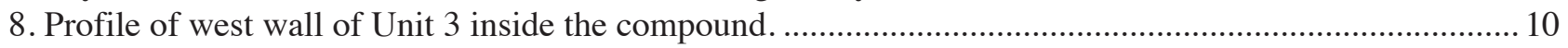

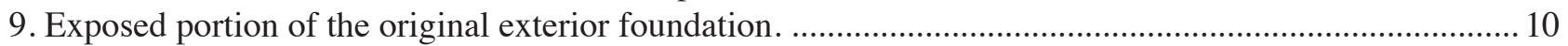

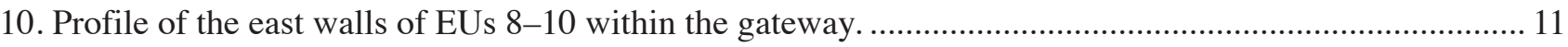

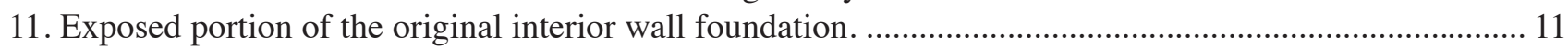

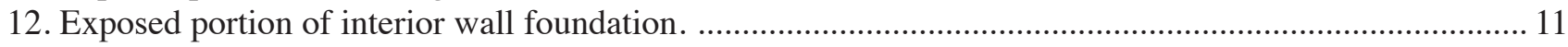

13. Profile of eastern gate archway showing connection of reconstructed and original portions

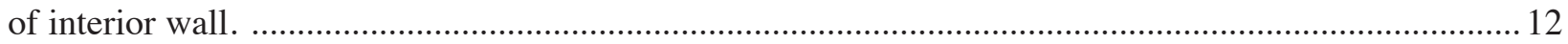

14. Plan map of excavated trench showing foundation sections and pipe trench disturbances. ..................... 13

15. Lithic tools. 20

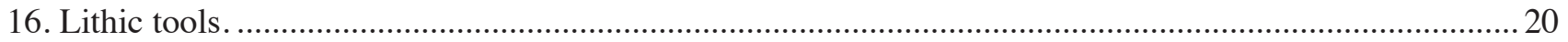

\section{Tables}

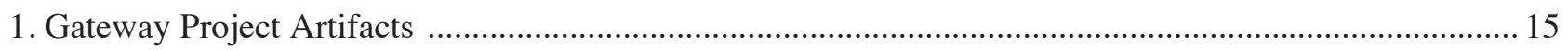

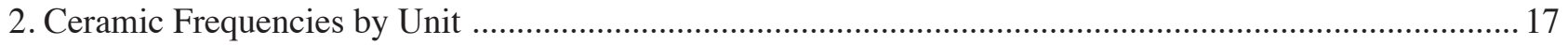

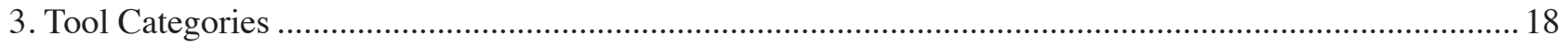

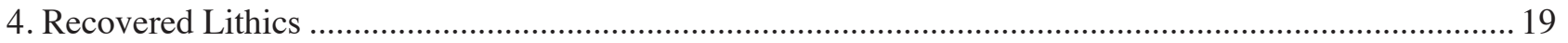

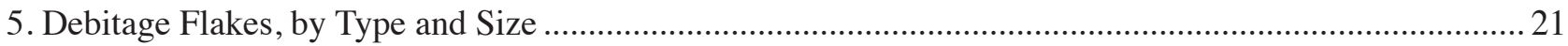

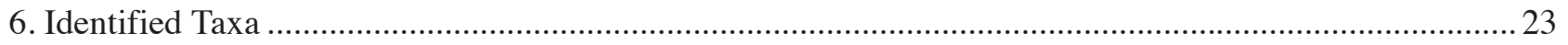




\section{Acknowledgments}

The author wishes to acknowledge the support provided by the staff of the National Park Service before, during, and after this project. Ron Treants of the Denver Service Center and Steve Whitesell and Alan Cox with the San Antonio Missions National Historical Park expedited the administrative portions of the project. Special thanks

are due to Harry Little and his grounds crew who provided invaluable assistance with the massive amount of hand digging required to protect the mission footings.

I would also like to thank the support group at the Center for Archaeological Research. Anne Fox and Robert J. Hard as always shared their expertise. Owen Ford, Chris Horrell, Andrew Scease, Ed Johnson, and Bruce Moses made up the field crew. Thanks to Barbara Meissner and Johanna Hunziker for their insightful analyses, to Bruce Moses and Chris Butler for the illustrations, and to James Rodriguez for formatting the report. As always, the final editing by Marcie Renner made the report intelligible. 


\section{Introduction}

In April 1996, the Center for Archaeological Research (CAR) of The University of Texas at San Antonio (UTSA) performed archaeological investigations as part of final-stage improvements associated with the construction of the National Park Service Visitors' Center at Mission San José y San Miguel de Aguayo. The work was conducted in the vicinity of the southeast gate where a 26-inch storm drain to channel rain water away from the mission compound was planned. This drain requires a trench -36 inches wide by $7 \mathrm{ft}$ deep-running from a point $22 \mathrm{ft}$ inside the mission compound, through the southeast gateway, and connecting with an existing drainage system $100 \mathrm{ft}$ southeast of the gate. The current phase of investigation was designed to recover data from Spanish colonialperiod deposits that would be impacted by this proposed construction. The project was performed for the National Park Service (NPS), manager of the missions within the San Antonio Missions National Historical Park, under Texas Antiquities Permit number 1649.

Previous investigations conducted by CAR in 1993 at Mission San José included limited testing of the area around the southeast gate (Hard et al. 1995). These investigations consisted of four test units placed within the gateway, and one unit just east of the gate inside the compound. Results of this portion of the project indicated that undisturbed Colonial-period deposits were present beginning 15-20 inches below the surface in front of and inside the gateway. A stone alignment believed to represent a portion of the original mission wall was also identified 25-35 inches below the surface along the outer edge of the gateway. Only limited testing - two backhoe trenches - was conducted during this original project in the area directly south of the gate (Hard et al. 1995).

Based on this information, a data recovery program was designed for the trench impact area within the compound and gateway. These investigations consisted of eight 4-x-4-ft units, one 6-x-6-ft unit, and two irregular units excavated directly over the proposed path of the drainage trench. A testing and monitoring program was also designed for the drainage impact area outside the compound walls. Nine shovel tests at 10-m intervals and three backhoe trenches were placed along the portion of the drainage trench extending beyond the compound walls (Figure 1).

The excavations within the compound resulted in the recovery of a variety of Colonial and post-Colonial artifacts including ceramics, chipped stone, glass, metal, and a large quantity of animal bone. Portions of the original exterior and interior walls of the mission compound were uncovered extending across the present and obviously modern southeast gateway.

\section{Site Setting and Background}

Extensive archival research was conducted into the history of Mission San José in preparation for the 1993 CAR archaeological investigation. The interested reader is referred to Hard et al. 1995 for a detailed account of what is known about the Colonial-period layout, land use and ownership after secularization, and late-nineteenth- and early-twentieth-century modification and reconstruction activities at the mission. Aside from a brief summary of the general history of Mission San José, the background section of this report focuses on the information that most directly pertains to the area immediately around the present-day southeast gateway.

Mission San José y San Miguel de Aguayo is the second of five missions established by Franciscan missionaries along the banks of the San Antonio River. Originally founded about 3.5 miles south of Mission San Antonio de Valero (the Alamo) by Zacatecan friars in 1720 , the mission was reestablished at its present location on the west side of the river sometime between 1724 and 1727 . During the next 70 years, as many as 336 Coahuiltecan Indians lived at the mission, building a granary, a friary, stone Indian houses, and two successive stone churches (Habig 1978; Ivey et al. 1990).

The early Indian houses were most likely arranged along the present wall lines, but San José was an open village until ca. 1768 when the walled enclosure with four gates, one in each wall, is first described (Habig 1978:144; Ivey et al. 1990:137). Mud and stone Indian houses with wooden front doors formed the 


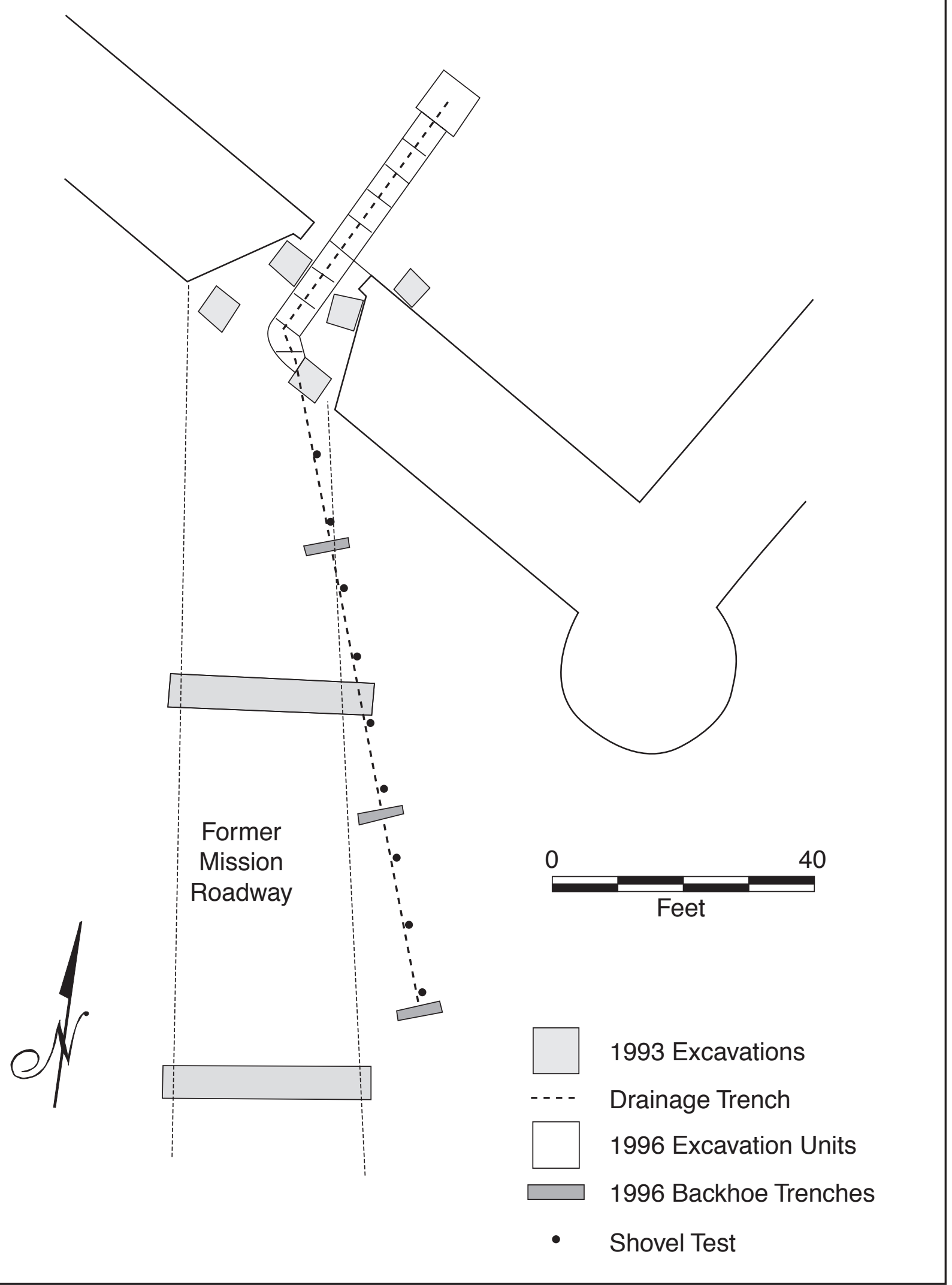

Figure 1. Areas of investigation in the southeast gateway. 
enclosing wall of the compound described in 1786 (Ivey et al. 1990). By 1823 however, when the mission property appraisal preceding secularization was made, few of the houses were still standing; only two remained on the south wall. In this 1786 description, no mention was made of a gate in the south wall, but measurements given for existing houses and standing wall portions leave a gap of $21 \mathrm{ft}$ for an opening somewhere along the south expanse (Ivey et al. 1990:142).

With final secularization in 1824 , the mission compound and surrounding irrigated lands were deeded to the remaining mission Indians and various San Antonio residents. People continued to live within the compound and, as the old Indian quarters fell into ruin, new homes were constructed along the mission walls. Records can be traced claiming private ownership of sections along the wall from as early as 1815 until 1941 when the entire property was acquired by the state of Texas. In 1941 Mission San José was designated a National Historic Site and a Texas State Historic Site. It, along with three other San Antonio missions, became part of the San Antonio Missions National Historical Park in 1978. In 1983, NPS assumed a fully active presence at Mission San José (Hard et al. 1995).

The mission compound was reconstructed in its present configuration in the 1930s-1940s based on research and designs by architect Harvey P. Smith, Sr. As early as 1918, Smith noted that huts had been built upon the ruins and that any remaining wall foundations would probably disappear within a few years (Clark 1978). Aerial photos of the mission from 1920 and 1932, prior to the Smith reconstruction, show the enclosing walls had entirely collapsed by this time and Mission Road is clearly visible running diagonally across the compound from what would have been the southeast corner to the front of the granary (Figures 2 and 3 ).

A road into the mission appears on the 1881 Lazzeler tract map (Figure 4) labeled as the "new road to San Juan" (District Court Records [DCR], Office of the District Clerk, Bexar County Courthouse, San Antonio, Volume K:103). This "new" road appears to enter the mission compound through an opening close to the center of the south wall as suggested by Ivey et al. (1990:142). However, when Mission Road became an official county road in 1888 (MCC, Book E: November 21, 1888), its location was established at the southeast corner of the compound. The location chosen for the southeast gate of the mission in the 1930s was evidently based on this late nineteenthcentury placement of Mission Road and not on archaeological or archival evidence.

\section{Previous Investigations}

Prior to the 1993 CAR project, archaeological investigations within and adjacent to Mission San José were limited to small salvage and monitoring operations (Figure 5). Schuetz (1970) monitored the excavation of sprinkler system trenches. D. Fox (1970) tested and monitored the relocation of a large tree and the installation of sewer and electric lines in the north part of the compound. Clark (1978) excavated four units next to standing walls to access climatic effects to the structures. In 1974 and 1976 Roberson and Medlin conducted salvage operations inside three rooms in the southwest corner of the compound in advance of construction activities (Roberson and Medlin 1976). These investigations indicated that possibly intact Colonial-period deposits were present at varying depths throughout the compound. Four other investigations by Clark and Prewitt (1979), Henderson and Clark (1984), Hafernik and Fox (1984), and Fox and Cox (1991) were conducted outside the mission compound. The results of these investigations indicate that post-Colonial activities have caused a greater degree of disturbance outside the confines of the mission walls.

The 1993 CAR project at Mission San José (Hard et al. 1995) was the first archaeological investigation designed to provide a comprehensive evaluation of subsurface Colonial-period deposits within the mission compound and to test areas outside the compound to be impacted by construction of the visitors' center. Four distinct areas of investigation (Areas A-D) were identified in the research design (Figure 6). In Area A, the triangular track formed by Roosevelt Road, Napier Avenue, and Woodhull Drive, a series of shovel tests was excavated to test the area directly impacted by the visitors' center 


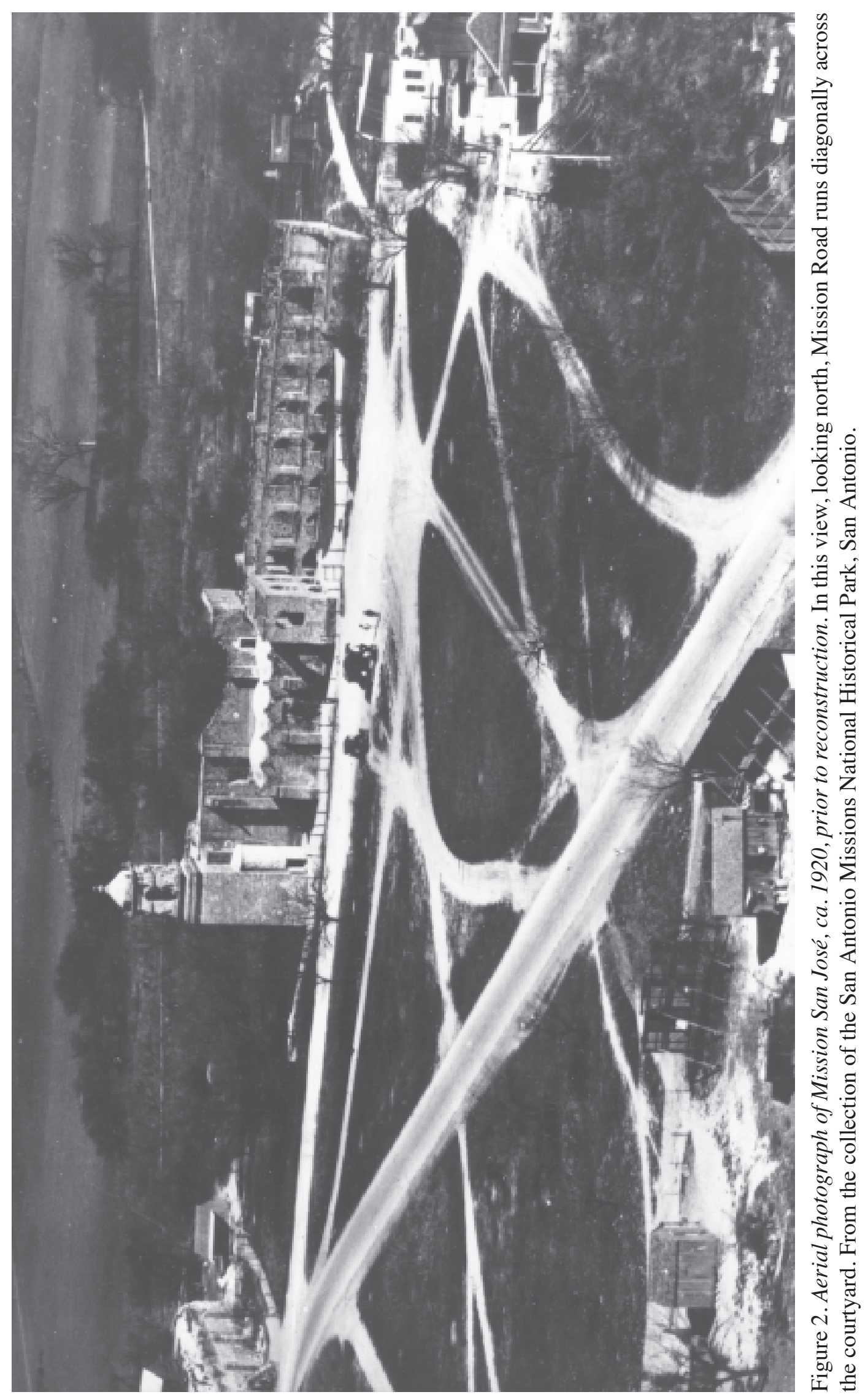




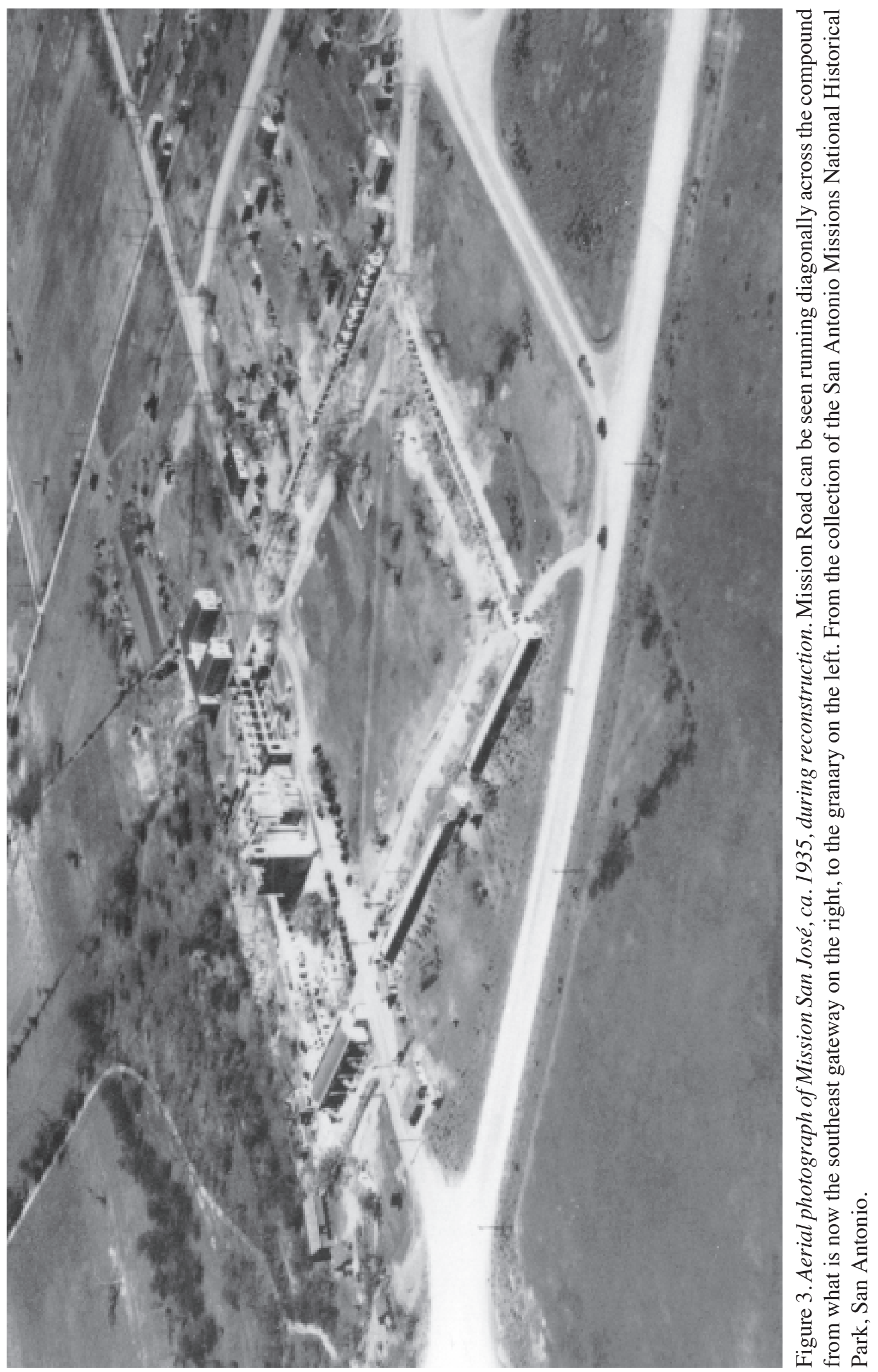




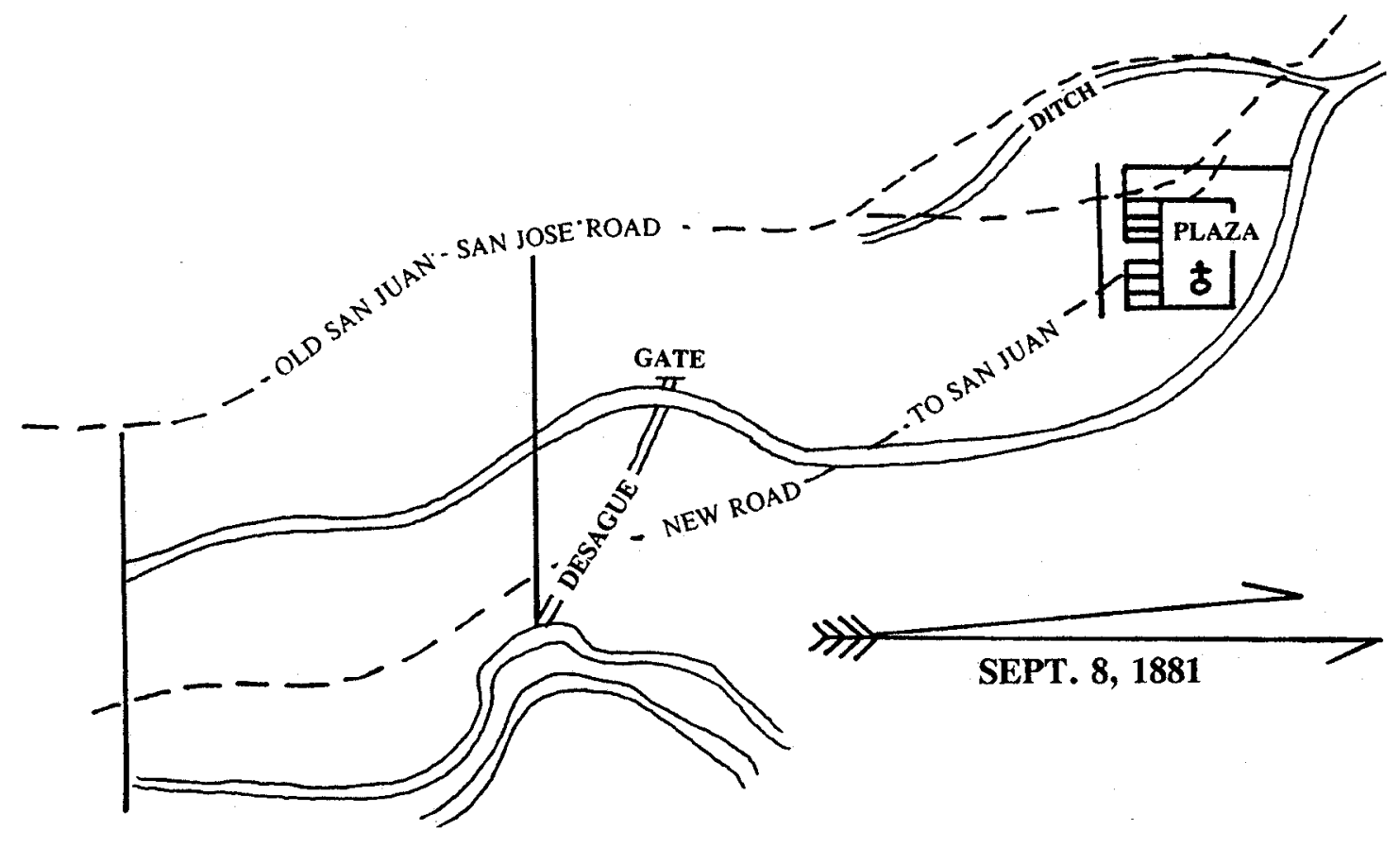

Figure 4. Early location of New Road through Mission San José. Adapted from the 1881 M. W. Merrich survey of the Lazzeler tract. DCR K:103.

building and the rerouting of Napier Avenue. Backhoe trenches and one large (50-x-25-ft) Gradall trench were also excavated in an attempt to relocate a possible jacal feature identified by Henderson and Clark (1984). No artifacts or features of any age were encountered. A linear strip east of the compound (Area C) was investigated by backhoe in search of remaining portions of the Acequia Madre. A portion of undisturbed acequia was recognized 18 inches below the surface in the northernmost trench (Hard et al. 1995). Area D, the interior compound within the confines of the mission walls, was investigated through a series of 83 screened shovel tests. These tests were placedat $50-\mathrm{ft}$ intervals along nine gridlines. Concentrations of Colonial-period artifacts were identified in undisturbed context in the southeast, southwest, and west-central portions of the compound. In general, these deposits were encountered 12-15 inches below the present surface (Hard et al. 1995).

The investigations in Area B, the southeast gateway, were designed to assess disturbances within the gateway and to locate and document the old mission trace (road) in preparation for the relocation of the main entrance and walkway from the visitors' center. Two backhoe trenches were excavated outside the compound and six test units were placed within the gateway and along adjacent walls. The bed of the 1880s Mission Road was identified in both backhoe trenches. Test excavations in the vicinity of the gateway consisted of one 3-x-3-ft unit abutting the interior wall to the east of the gate, one 4-x-4-ft unit abutting the exterior western edge of the corner bastion, and four 4-x-4-ft units within the gateway. These investigations revealed that deposits in the upper 15-20 inches contained gravel and caliche road base from the 1880s-era Mission Road and debris from the 1930s reconstruction activities, along with a light scatter of late-nineteenth-century through modernperiod artifacts. Deposits below this depth appeared to contain undisturbed Colonial-period accumulations of ceramics, lithic materials, and faunal remains (Hard et al. 1995). 


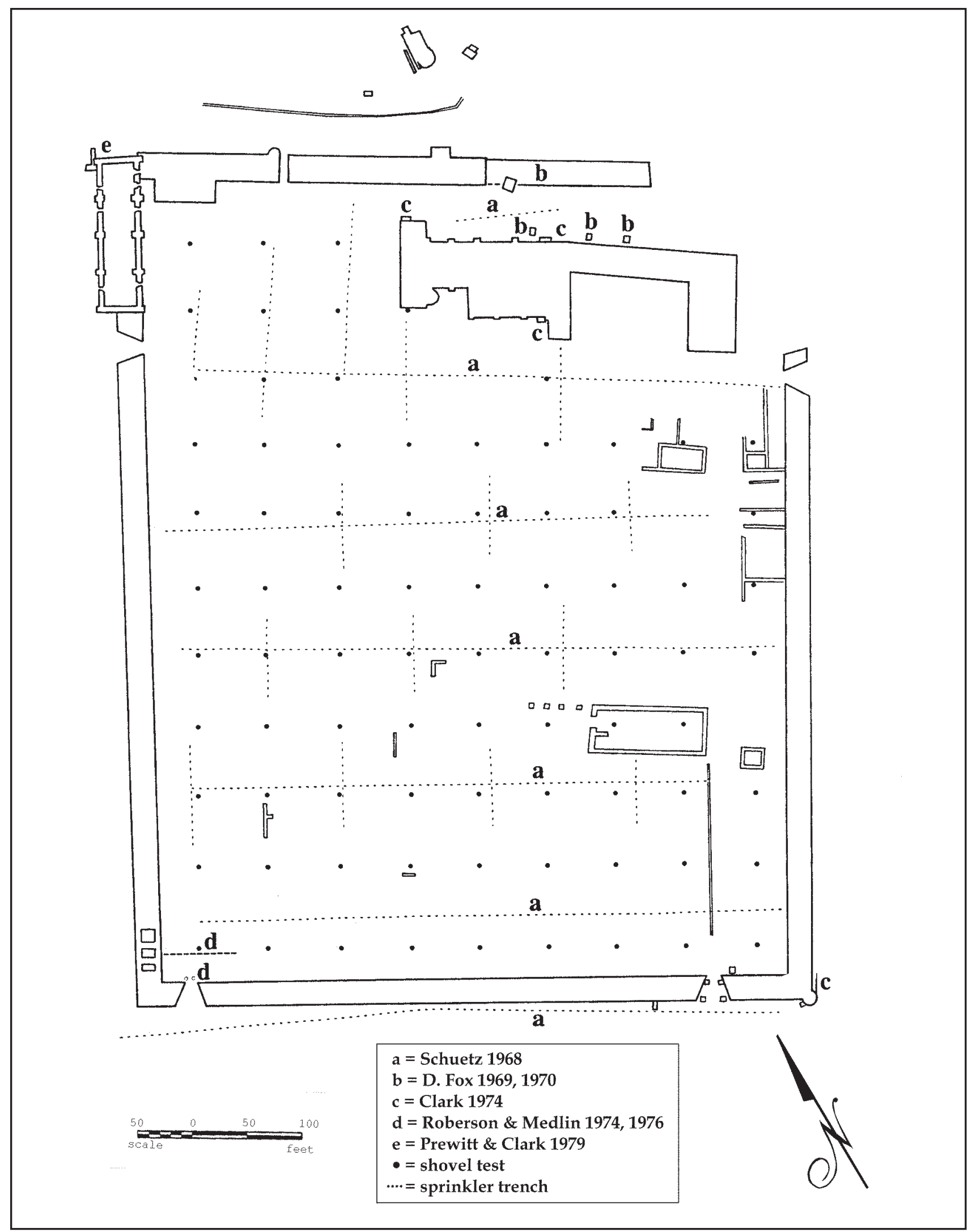

Figure 5. Locations of previous archaeological investigations. From Hard et al. 1995. 


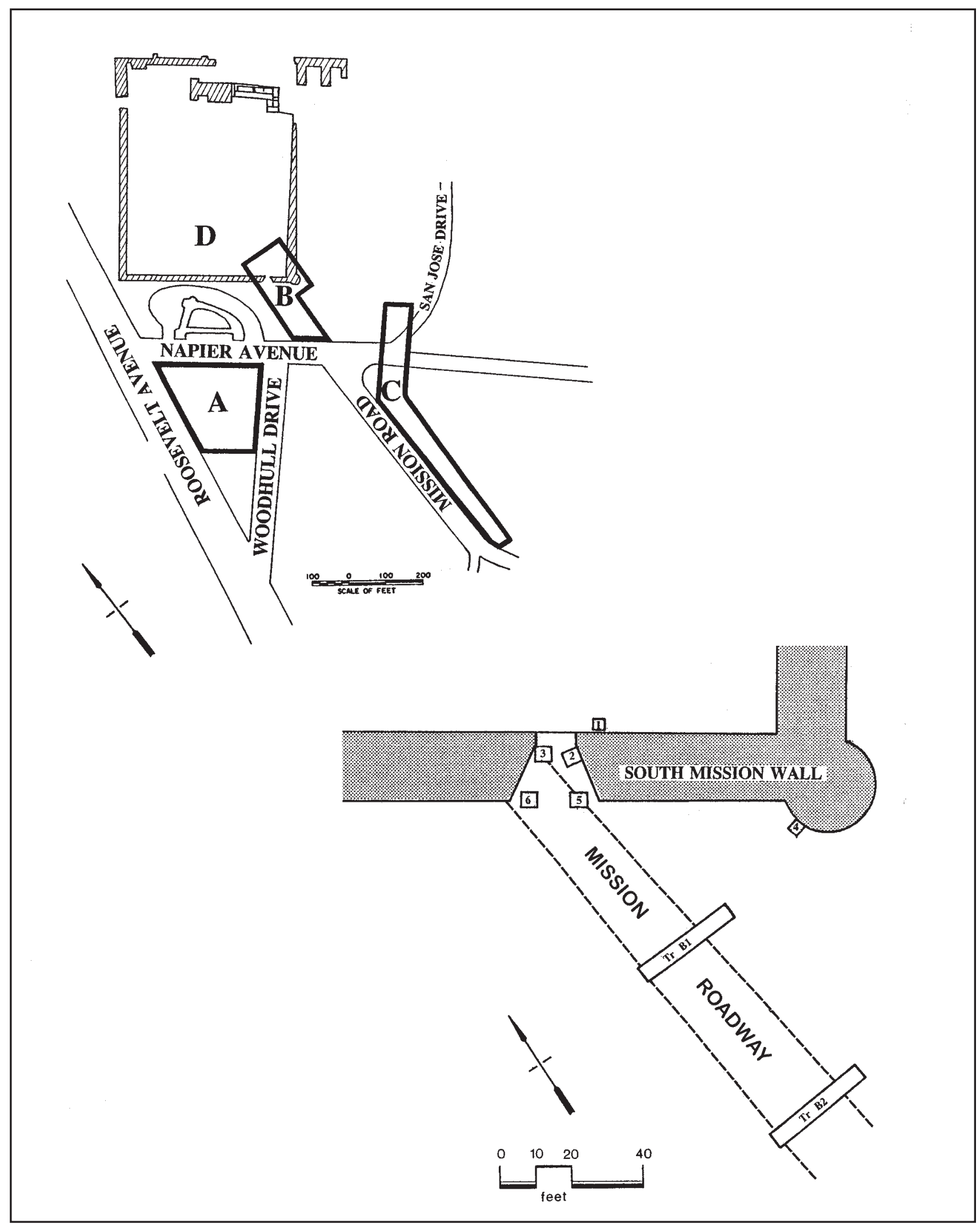

Figure 6. Areas of 1993 CAR archaeological investigations (top) with details of Area B excavations (bottom). From Hard et al. 1995. 


\section{Methodology}

Based on the 1993 CAR investigations, a data recovery program was designed for the trench impact area within the compound and gateway. Because the impact area outside the compound walls had previously been disturbed by construction of Mission Road and the presence of commercial buildings and private residences, a testing and monitoring program was designed for this section of the drainage route. The fieldwork completed in 1996 consisted of the excavation of nine shovel tests and three backhoe trenches outside the mission compound. One 6-x-6-ft test unit, eight 4-x4-ft test units, and two irregularly shaped units were excavated within the southeast gateway and southern section of the mission compound (Figure 1).

Prior to beginning the archaeological investigations, the path of the drainage-system trench was delineated by the construction engineer. Shovel tests, numbered 1-9 consecutively southward from the wall, were placed at 10-ft intervals along the portion of the trench which extended outside the walled compound to test for intact Colonial deposits within this area which had served as a county road from the 1880 s. These tests were dug in arbitrary 12-inch levels to sterile soil and screened through $1 / 4$-inch hardware cloth to insure consistency with information obtained from the previous CAR investigations. Brief soil descriptions and artifact counts were recorded by level on shovel-test forms. Three backhoe trenches, 36-48 inches deep, were excavated across the proposed drainage line to search for more deeply buried archaeological deposits. Walls and backdirt from these trenches were inspected for artifacts and profiles were drawn of each trench. Actual excavation of the storm drainage trench was monitored.

The results of the 1993 CAR investigations in the vicinity of the southeast gateway indicated that the top 15-20 inches in this area had previously been disturbed by reconstruction activities and the presence of Mission Road. We therefore decided that monitored removal of these disturbed deposits inside the compound and within the gateway was appropriate. A Bobcat with a 48 -inch bucket removed the 15-20-inch overburden in 2-3-inch levels. This activity was supplemented by pick and shovel work where necessary. Mechanical removal within the trench was halted at the base of the rubble- and road-fill layer which varied from 10 inches below the surface within the compound to 20 inches below the surface within the gateway opening.

One 6-x-6-ft excavation unit (EU), eight 4-x-4-ft EUs, and two irregularly shaped EUs were then laid out inside the trench cleared by the Bobcat. These units were labeled EU 0- EU 10, consecutively from north to south (Figure 7). Vertical datums were established three inches above original ground level along the east side of the cleared trench. Elevations were shot for datums and starting depths of excavations units. Starting elevations for EUs varied from 13-23 inches below datum (bd), 10-20 inches below the original surface (bs). The initial hand-excavated level of each unit was brought to a depth 20 inches bd, succeeding levels were five inches in depth. Excavations continued to sterile soil. All hand-excavated dirt was screened through $1 / 4$-inch hardware cloth and artifacts were bagged by level. All units were photographed

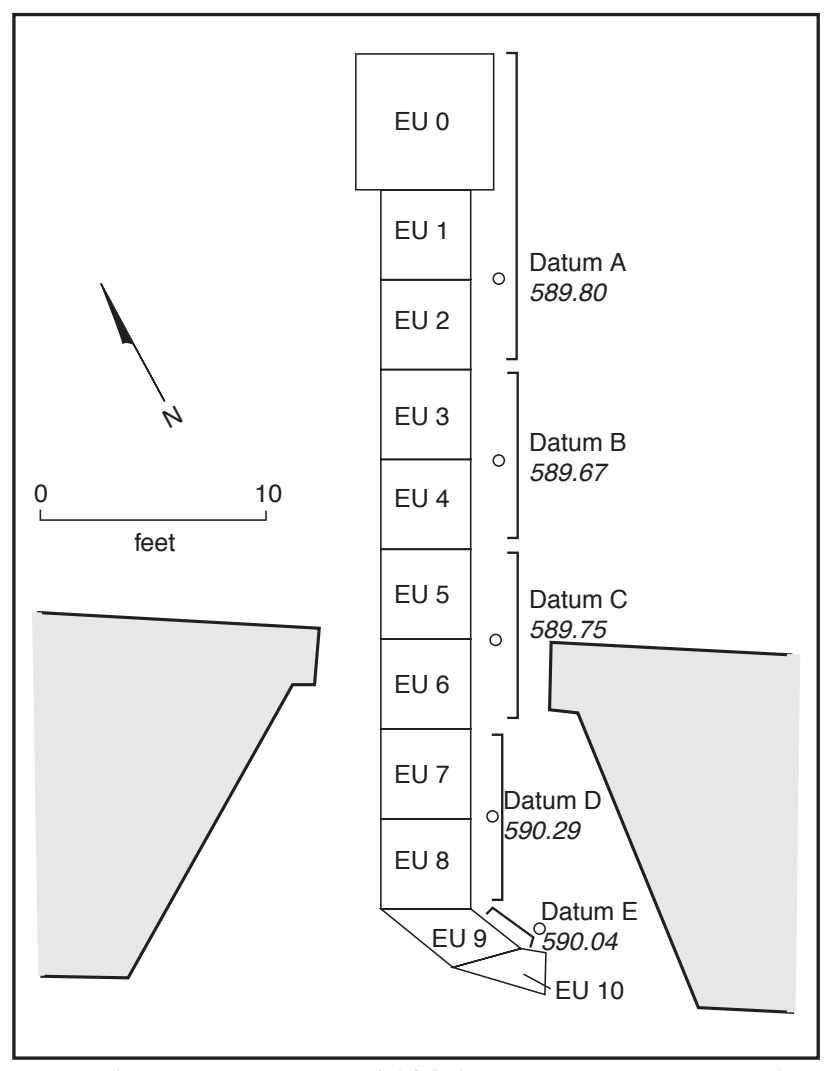

Figure 7. Layout of 1996 excavation units within the southeast gateway. Datum elevations (amsl) are given in italics. 
and profiled, and plan maps were drawn where appropriate.

\section{Results}

\section{Test Units}

Excavation of the 11 EUs within the compound and gateway resulted in the recovery of 2,366 artifacts and the identification of the foundation of the exterior and interior portions of the walls that originally spanned the current gateway opening. The profile of EU 3 inside the compound (Figure 8) confirms the 1993 CAR finding that the upper 13-15 inches in the gateway vicinity are composed of limestone rubble and road gravels. Below these disturbances is the artifact-bearing layer of mottled graybrown clay which grades to sterile dark brown clay at a depth of 27 inches below the surface.

The exterior wall foundation identified during the 1993 CAR testing was relocated and an additional portion was exposed (Figure 9). This portion of the exterior foundation was exposed 19 inches below the surface at the southern limits of the project trench in EUs 9 and 10. It extends to a depth 35 inches below the surface and is approximately 35 inches wide. The foundation is composed of uncut sandstone and limestone held together by lime and sand mortar. Approximately 15 inches of this foundation had been removed during the installation of the fourinch main water line now serving the mission. Removal of the fill from the water-pipe trench provided a cross-section view of the foundation which shows the outline of the two-inch thick trench dug for construction of the original foundation (Figure 10).

A section of the interior wall foundation was also discovered 12 inches below the modern surface, in EUs 5 and 6, in line with the existing reconstructed interior wall of the compound (Figures 11 and 12). This foundation extends to a depth 25 inches below the surface and is 27 inches wide. The foundation is

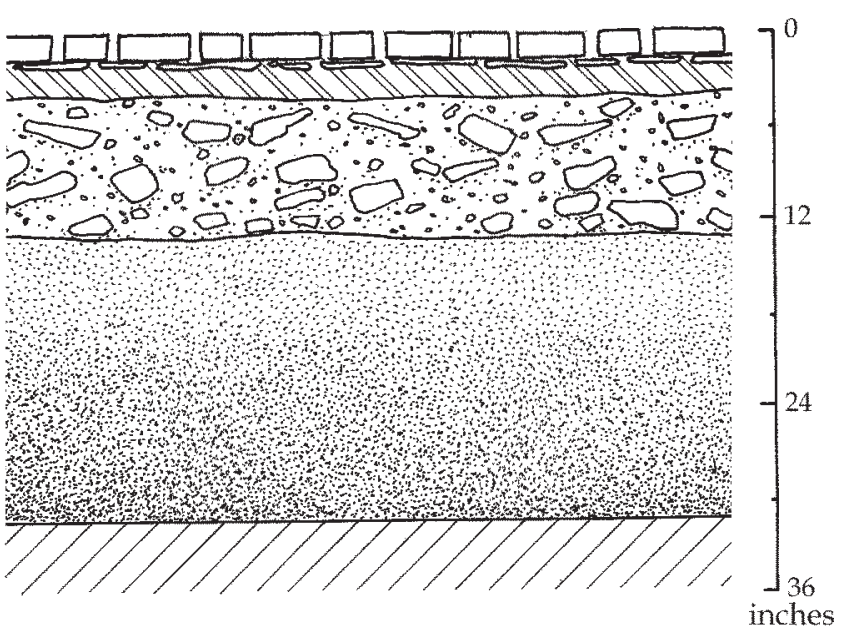
Gravel Road Base
Mottled Gray Clay
Unexcavated Area
Modern Brick Walkway
Thin Limestone Base
Orange Sand

Figure 8. Profile of west wall of Unit 3 inside the compound.

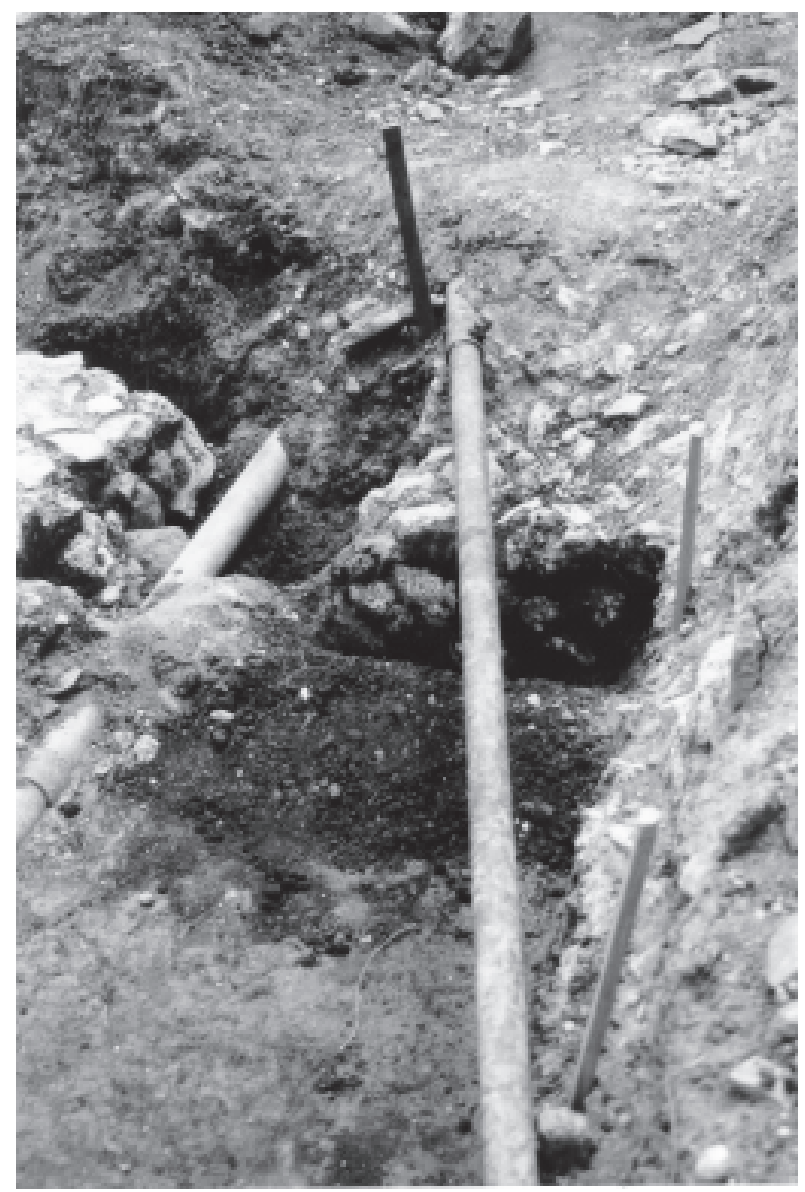

Figure 9. Exposed portion of the original exterior foundation. Looking south. 
composed of uncut pieces of sandstone and limestone that do not appear to have been laid systematically for the foundation. These stones are held together by uneven layers of fine-grained, lime and sand mortar. No evidence of a construction trench was found with the interior foundation.

Approximately 12 inches of the interior foundation had also been removed during installation of main water line. The fill from this water-pipe trench was removed and excavations were extended eastward an additional 22 inches to the edge of the reconstructed mission archway. Figure 13 shows the reconstructed wall is joined to the original foundation by a layer of concrete 15 inches below the modern surface.

Modern water and sprinkler pipes present in the project area are shown in Figure 14. The disturbance from these utilities was limited for the most part to the pipe trenches and left large sections of the Colonial deposit intact. However, the previous installation of the four-inch water pipe created a 15 -inch opening in both the exterior and interior portions of the original wall foundations within the gateway.

The discovery of the breach in the Colonial foundations led to a reconsideration of the path of the new drainage system. With approval of THC and NPS representatives, the drainage trench was realigned to take advantage of the existing openings. Six inches of rock were removed from each side of the opening in the exterior foundation and 12 inches were trimmed from the western edge of the opening in the interior foundation to accommodate the new 26-inch drainage pipe. Park workers removed the soil adjacent to the exposed foundations by hand, leaving a five-foot-thick bulkhead

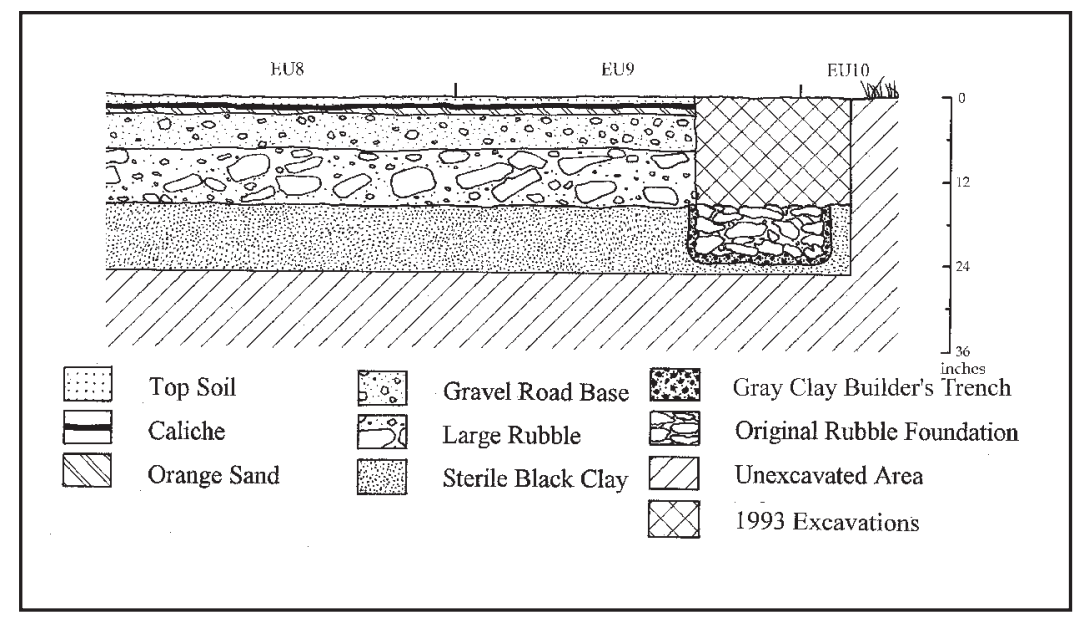

Figure 10. Profile of the east walls of EUs 8-10 within the gateway.

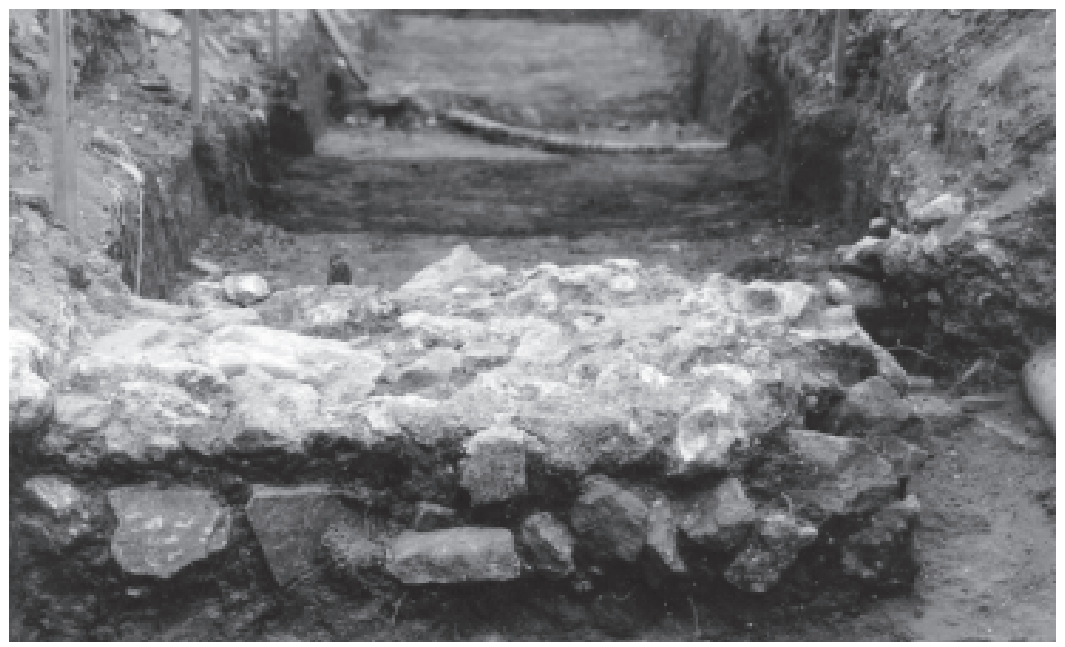

Figure 11. Exposed portion of the original interior wall foundation. Looking north.

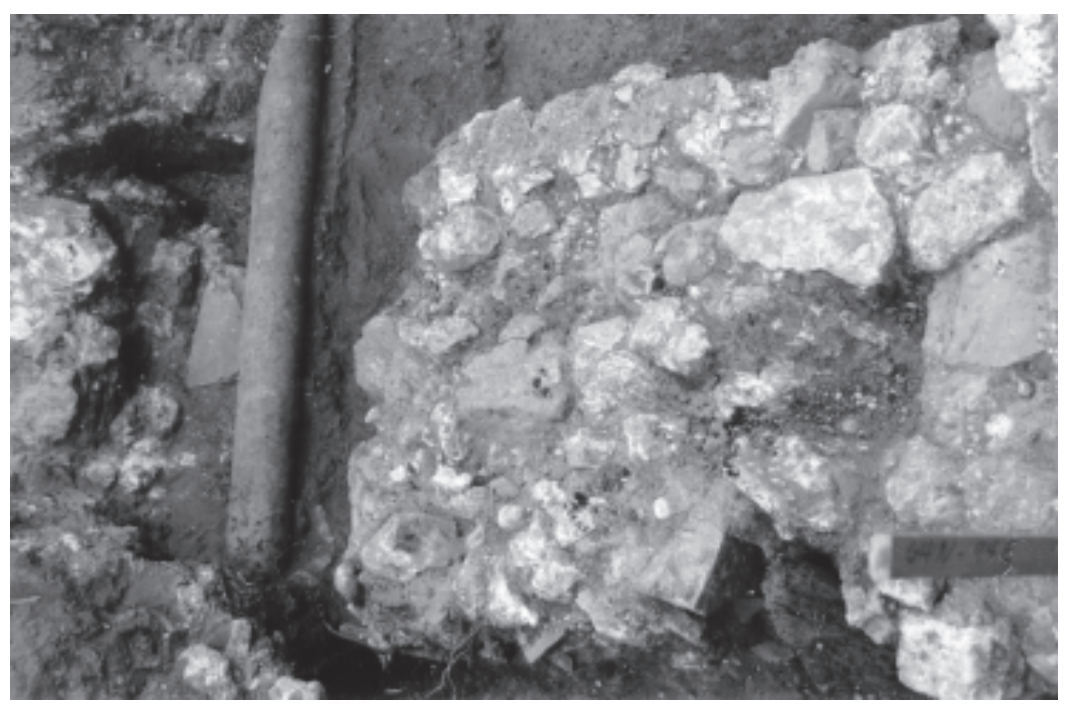

Figure 12. Exposed portion of interior wall foundation, top view. 


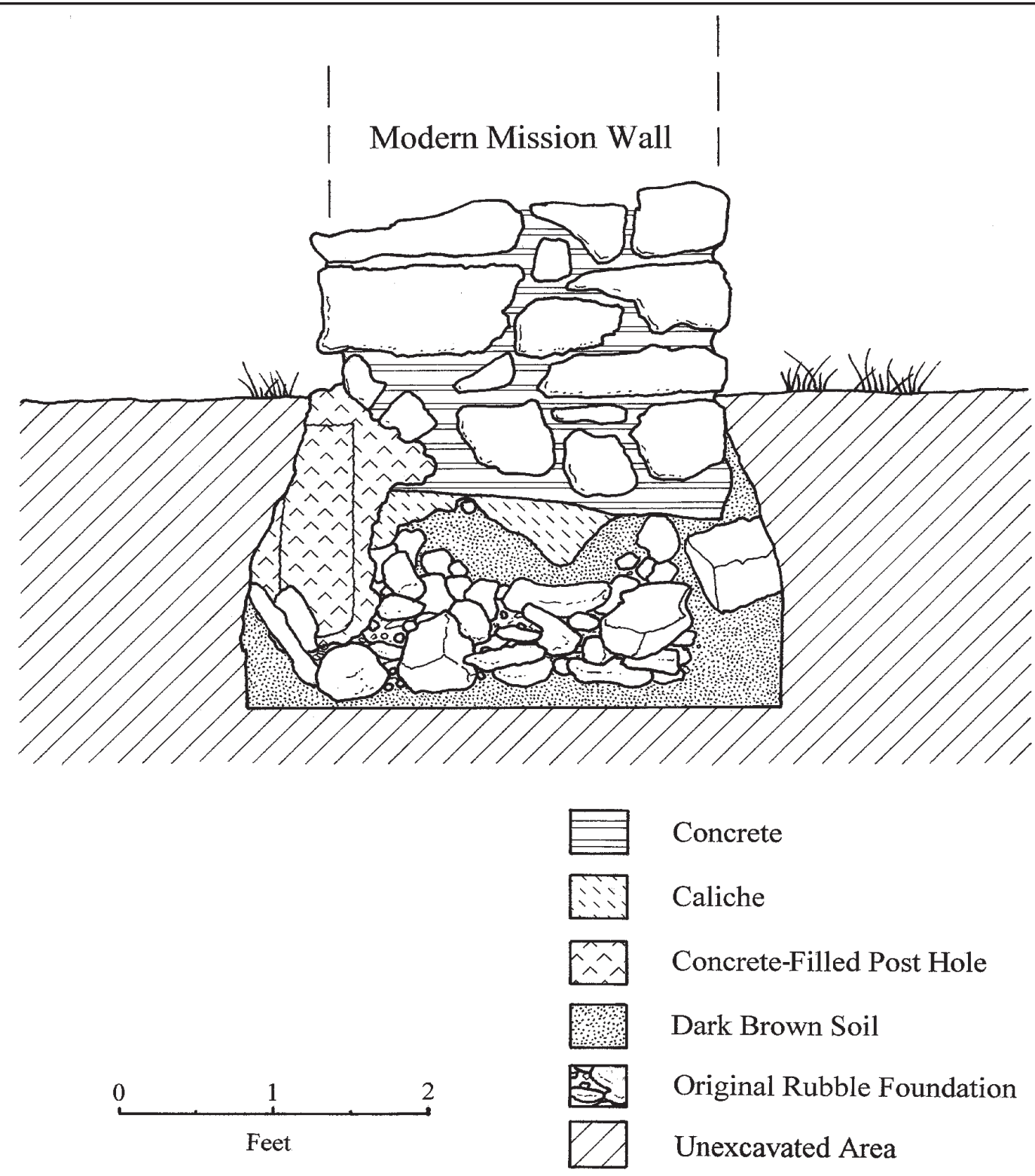

Figure 13. Profile of eastern gate archway showing connection of reconstructed and original portions of interior wall.

beneath the foundation for support. The opening below the five-foot support bulkhead was widened by hand to three feet to accommodate the new storm drain which was slipped under the interior Colonial foundation.

\section{Shovel Tests}

Excavation of nine shovel tests and three backhoe trenches along the trench line outside the compound walls revealed deposits dominated by a gravel and tar road base and twentieth-century trash and animal bone. Compacted gravels and caliche were encountered in the upper 12 inches of each test. This layer was underlaid by a homogeneous stratum of dark brown clay loam. Sterile deposits of black clay were consistently encountered at depths in excess of 22 inches below the surface. This depositional pattern was repeated in each of the three backhoe trenches. 


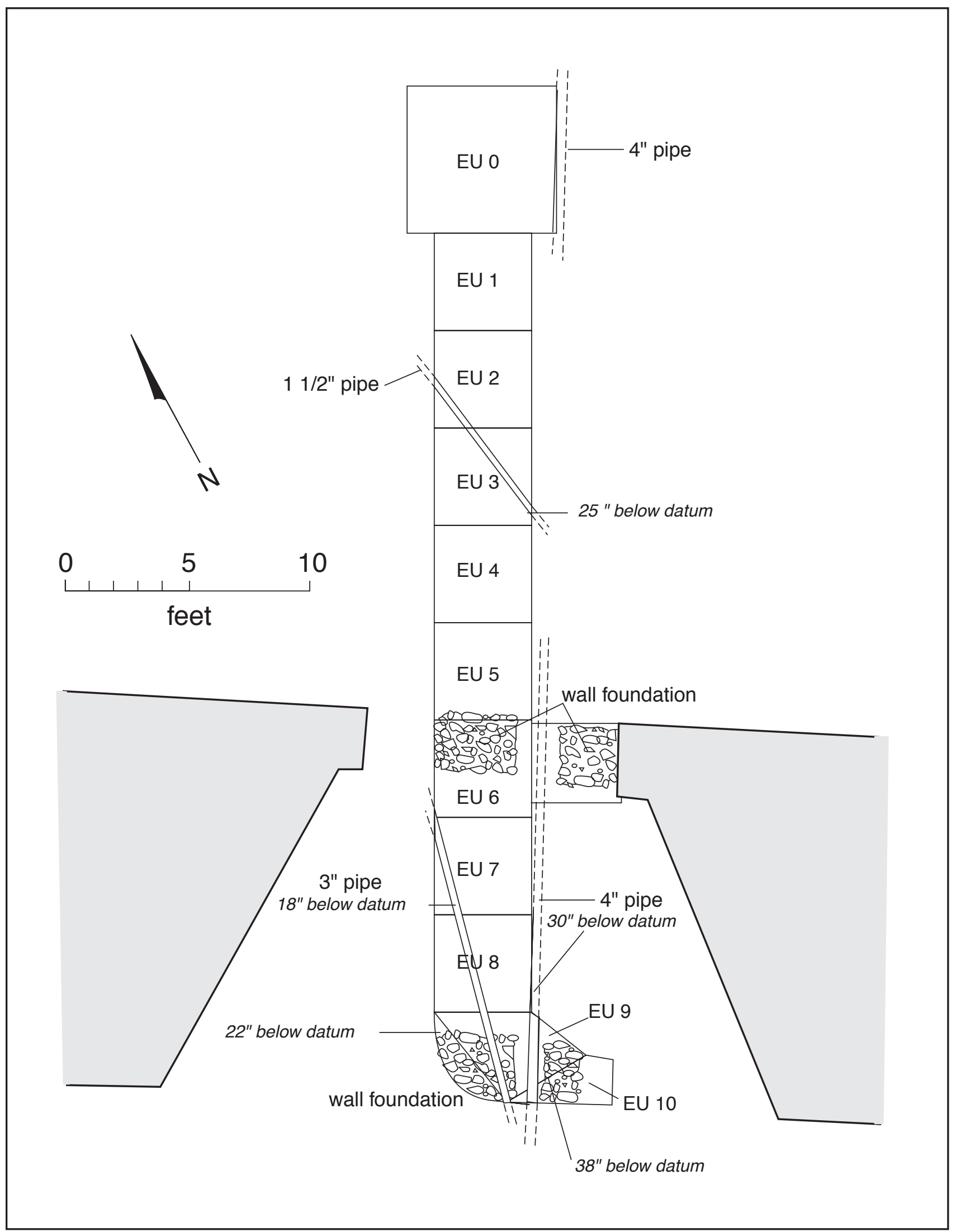

Figure 14. Plan map of excavated trench showing foundation sections and pipe trench disturbances. 
Of the 227 non-faunal artifacts recovered from the shovel tests conducted outside the mission compound, 223 are associated with post-Colonial use of the mission (Table 1). Glass - clear, brown, green, and white-was the most abundant artifact type, accounting for 68 percent $(n=155)$ of the items recovered outside the mission wall. The one piece of undecorated brownware, two pieces of lead glazed, and one piece of chipped stone that are typical of Colonial artifact assemblages, were recovered from depths between 12-24 inches below the surface. However, modern metal and glass were also recovered from these levels, indicating that deposits outside the wall are disturbed. Sterile deposits of black clay were consistently encountered at depths in excess of 22 inches below the surface.

\section{Artifact Descriptions}

For this discussion, artifacts types have been divided into two gross temporal categories: Colonial period and post-Colonial period. Artifacts defined as Colonial period include undecorated brownware, lead-glazed, and tin-glazed ceramic sherds; chert lithics; animal bone; mussel shell; and two cut-glass jewelry decorations. Glass, metal, undecorated and decorated whitewares, stoneware, porcelain, construction materials, and plastic are listed as post-Colonial artifacts. Placement of faunal remains in the Colonial period, while somewhat arbitrary, is based on the strong association between animal bone and Colonialperiod ceramics identified by Hard et al. (1995). Artifact totals and proveniences are given in Table 1 . Details of the ceramic, lithic, and faunal assemblages appear in the following sections.

\section{Ceramics}

\section{Colonial-Period Ceramics}

\section{Brownwares}

Unglazed wares attributed to Native American potters at San Antonio missions comprise this category (Dial 1992; Fox 1993; Hard et al. 1995; Ivey and Fox 1982). Two varieties of brownware were recovered during this phase of investigation. Goliad ware, characterized by coarse-grained tan to reddish-brown paste with readily visible bone temper and distinctive dark organic streaks from incomplete firing, is the most frequent ceramic in the collection. Fox et al. (1976:67) suggest that Goliad ware is a direct continuation of the local Late Prehistoric ceramic tradition known as Leon Plain in central and south Texas. Valero ware, a wheel-made pottery with sand-tempered, tan paste was also recovered. These unglazed brownwares make up over 88 percent of the ceramic assemblage $(n=287)$.

\section{Lead Glaze}

Lead-glazed wares have been made in Mexico and brought into Texas since the 1750s (Ivey and Fox 1982; Meskill 1992:23). They can be divided into two subtypes based on wall thickness and decoration. The thick-walled variety, usually considered a utility ware, has a sandy orange paste and a thin lead-based glaze. The yellow or green glaze is commonly unevenly applied, sometimes covering the entire vessel, sometimes found only on the upper half and interior of the vessel. Occasionally, decorations include a green or brown band around the rim and center of the base (Ivey and Fox 1981:34). The thin-walled variety, called Galera, was primarily used for chocolate and bean pots. Sherds have a fine paste and are decorated with cream-colored bands or dots and floral designs with an occasional green accent. The 12 lead-glazed sherds in this assemblage represent 3.6 percent of the total ceramic assemblage.

\section{Tin Glaze}

Tin-glazed ceramics are characterized by their decorated white opaque glaze covering a paste that ranges in color from cream to dark red. In Europe, the French produced tin-glazed wares known as faïence, the Dutch produced their version known as delftware, and the Spanish produced the type known as majolica. By the early 1600 s majolicas were being manufactured in New Spain by potters in Puebla, Mexico. These Mexican majolicas are distinguished from the European varieties by their shiny glaze and distinctive decorative patterns (Lister and Lister 1974). 
Table 1. Gateway Project Artifacts

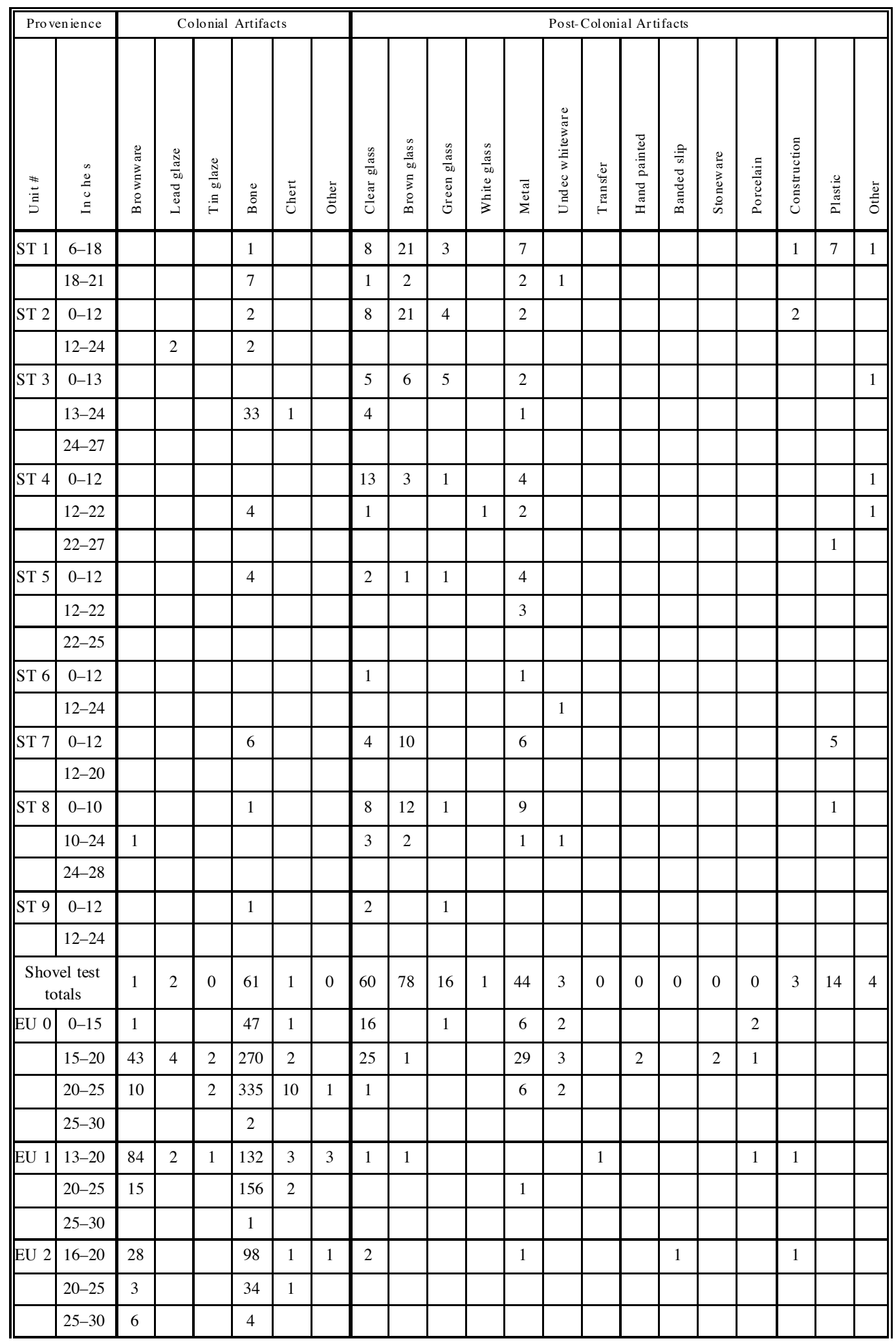


Table 1. continued

\begin{tabular}{|c|c|c|c|c|c|c|c|c|c|c|c|c|c|c|c|c|c|c|c|c|c|}
\hline \multicolumn{2}{|c|}{ Provenience } & \multicolumn{6}{|c|}{ Colonial Artifacts } & \multicolumn{14}{|c|}{$\begin{array}{l}\text { Post-Col onial Artifacts } \\
\end{array}$} \\
\hline 䓂 & 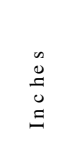 & 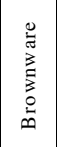 & 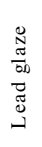 & 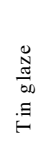 & $\begin{array}{l}\stackrel{0}{\bar{~}} \\
\end{array}$ & 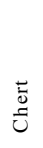 & 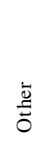 & 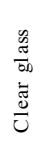 & 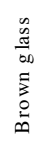 & 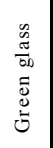 & 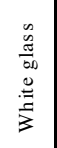 & $\frac{\bar{\sigma}}{\frac{\pi}{2}}$ & 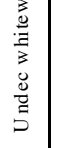 & 帝 & 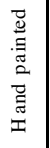 & 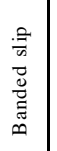 & 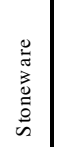 & 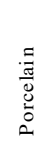 & 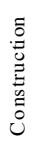 & $\begin{array}{l}\frac{.}{\underline{\underline{m}}} \\
\frac{\pi}{2}\end{array}$ & 总 \\
\hline \multirow[t]{3}{*}{ EU 3} & $15-20$ & 3 & 1 & & 33 & 1 & 1 & 2 & & & & 3 & & & & & & & 1 & & \\
\hline & $20-25$ & 8 & & & 44 & 1 & & & 2 & & & 2 & & & & & & & 1 & & \\
\hline & $25-30$ & 5 & & & 37 & & & 2 & & & & & & & & & & & & & \\
\hline \multirow[t]{2}{*}{ EU 4} & $15-20$ & 7 & & & 35 & 1 & 1 & 5 & & & & & & & & & & & 1 & & \\
\hline & $20-25$ & & & & 32 & 1 & & 1 & & & & & & & & & & & & & \\
\hline \multirow[t]{3}{*}{ EU 5} & $14-20$ & 23 & 1 & 1 & 128 & 3 & & 4 & 2 & & 1 & 3 & & & & & & & 4 & & \\
\hline & $20-25$ & & & & 5 & & & 4 & 2 & 1 & & & & & & & & & & & \\
\hline & $25-30$ & & & & & & & 1 & & & & & & & & & & & & & \\
\hline \multirow[t]{3}{*}{ EU 6} & $15-20$ & 1 & & & 11 & & & 5 & 5 & & & 1 & & & & & & & & & \\
\hline & $20-25$ & & & & 1 & & & & & & & & & & & & & & & & \\
\hline & $25-30$ & & & & 2 & & & & & & & & & & & & & & & & \\
\hline \multirow[t]{2}{*}{ EU 7} & $23-30$ & 20 & & & 52 & 3 & & 7 & 6 & 1 & & 2 & & & & & & & 3 & & \\
\hline & $30-35$ & 2 & & & 11 & & & 2 & 3 & & & & & & & & & & & & \\
\hline \multirow[t]{2}{*}{ EU 8} & $23-30$ & 15 & 1 & & 108 & 1 & & 11 & 28 & 3 & 2 & 7 & 1 & & & & & & 3 & & 1 \\
\hline & $30-35$ & 1 & & & 13 & & & & & & & & & & & & & & & & \\
\hline \multirow[t]{2}{*}{ EU 9} & $22-25$ & 1 & 1 & & 5 & & & 3 & 5 & & & 1 & & & & & & & & & \\
\hline & $25-30$ & 4 & & & 20 & 6 & & 16 & 31 & 1 & & 3 & & & & & & & & & 2 \\
\hline \multirow[t]{2}{*}{ EU 10} & $19-25$ & 5 & & & 31 & & 1 & 13 & 42 & 7 & & 2 & & & & & & & 1 & & \\
\hline & $30-35$ & 1 & & & 1 & & & & 1 & & & & & & & & & & & & \\
\hline \multicolumn{2}{|c|}{ Unit Totals } & 286 & 10 & 6 & 1648 & 37 & 8 & 121 & 129 & 14 & 3 & 67 & 8 & 1 & 2 & 1 & 2 & 4 & 16 & 0 & 3 \\
\hline \multicolumn{2}{|c|}{ Tot als } & 287 & 12 & 6 & 1709 & 38 & 8 & 181 & 207 & 30 & 4 & 111 & 11 & 1 & 2 & 1 & 2 & 4 & 19 & 14 & 7 \\
\hline & & & & & & & & Tota & I Ar & tifac & & 26 & & & & & & & & & \\
\hline
\end{tabular}

Mexican majolicas were exported to the northern Spanish frontier throughout the Spanish colonial period and continued to be popular until the early nineteenth century when European whitewares replaced them (Fox 1988; Gerald 1968; Goggin 1968; Lister and Lister 1974; Tunnell 1966). Majolicas are most frequently found at presidio sites and are associated with more prestigious segments of these Spanish outpost (Gerald 1968). Assemblages of majolica are rare at Spanish mission sites. For example, majolicas represent just three percent $(n=38)$ of the ceramics recovered during the 1993 CAR investigations within the compound at Mission San
José (Hard et al. 1995) and only 1.8 percent $(n=6)$ of the ceramics recovered during this project.

Puebla Blue-on-white, San Elizario Polychrome, and Aranama Polychrome are the types of majolica most commonly found in south central Texas and are the three varieties present in this collection. Puebla Blueon-white, popular from 1670-1800, is described as having decorations of varying shades of dark and light blue combined on a white background (Goggin 1968). San Elizario Polychrome, also described as having blue designs on a white background, is distinguished by brownish black emphasis lines on top of or beside the 
blue. Most commonly found on soup plates, this decoration was popular from 1750-1800 (Gerald 1968). Also present is a variation of Aranama majolica, Guanajuato, characterized by narrow or broad orange bands with green leaves and ball designs. On Florida sites, Aranama dates to between 1750-1800 (Deagan 1987:87); however, the Guanajuato variety found at south Texas mission sites is believed to be a later polychrome variation (Lister and Lister 1975) .

\section{Post-Colonial Ceramics}

Ceramic sherds from the post-Colonial period account for 6.4 percent $(n=21)$ of this collection. These include undecorated whiteware $(n=11)$, transfer print $(\mathrm{n}=1)$, hand painted $(\mathrm{n}=2)$, banded slip $(\mathrm{n}=1)$, stoneware $(n=2)$, and porcelain $(n=4)$. These post-1750 ceramic types are common in San Antonio mission assemblages and reflect the continued use of these facilities after secularization (Hard et al. 1995).

\section{Discussion}

All but six of the 326 ceramic sherds in this assemblage were recovered from the excavation units. The one piece of brownware and two pieces of lead glaze from the shovel tests came from 12-24 inches below the surface as did two of the three pieces of undecorated whiteware.

Colonial-period ceramics make up 94 percent $(n=302)$ of the 320 sherds recovered from the excavated units, with brownware sherds accounting for 95 percent $(n=286)$ of the Colonial assemblage (Table 2). Analysis of the spatial distribution of these sherds shows that 78 percent $(n=250)$ were recovered from EUs $0-5$, the area outside and in front of the living quarters defined by the original wall foundations (see Figure 14). Sixty-three percent $(n=201)$ of the total Colonial assemblage came from EUs 0-2, located $12-24 \mathrm{ft}$ from the foundation. This pattern of distribution suggests a cleared area was maintained in front of the living quarters.
Table 2. Ceramic Frequencies by Unit

\begin{tabular}{||c|c|c|c|c||}
\hline \multirow{2}{*}{ Unit } & \multicolumn{2}{|c|}{ Colonial } & \multicolumn{2}{c|}{ Post-Colonial } \\
\cline { 2 - 6 } & Count & \% of Total & Count & \% of Total \\
\hline EU 0 & 62 & 19 & 14 & 4 \\
\hline EU 1 & 102 & 32 & 2 & 1 \\
\hline EU 2 & 37 & 12 & 1 & 0 \\
\hline EU 3 & 17 & 5 & 0 & 0 \\
\hline EU 4 & 7 & 2 & 0 & 0 \\
\hline EU 5 & 25 & 8 & 0 & 0 \\
\hline EU 6 & 1 & 0 & 0 & 0 \\
\hline EU 7 & 22 & 7 & 0 & 0 \\
\hline EU 8 & 17 & 5 & 1 & 0 \\
\hline EU 9 & 6 & 2 & 0 & 0 \\
\hline EU 10 & 6 & 2 & 0 & 0 \\
\hline \hline
\end{tabular}

\section{Lithics}

\section{Barbara A. Meissner}

The arrival of the Spanish in San Antonio presaged the end of the lifeways followed by Native Americans in the area, but the change to a European-style culture did not take place immediately. Some native traditions continued throughout the mission period. One of these traditions was the manufacture and use of stone tools (Hester 1992). One account written in 1768 by Fr. Gaspar José Solís states, "los indios se ocupan en el trabajo que hay, los viejos en hacer flechas para los soldados [the men occupy themselves in the work that needs to be done, the old ones make arrows for the soldiers]" (Habig 1978:148). The term soldados seems to include Indian men skilled in the use of weapons, including bows and arrows, as these men are mentioned and enumerated in an earlier passage (Habig 1978:147). Except for occasional references like the above, no in-depth contemporary discussion by the Spanish describing stone tool manufacture and use by mission Indians are available. 
Although stone tools, the cores from which they were made, and the lithic debitage left from their manufacture are usually not a large percentage of the artifacts recovered during excavations at mission sites in San Antonio, they are usually present. Only 35 lithic artifacts were recovered during this project; a sample too small to permit an in-depth analysis. This report describes the recovered lithics and compares them to those recovered during the 1993 excavations at San José (Hard et al. 1995).

\section{Lithic Tools}

For the purposes of this report, lithic tool is defined as a piece of stone showing signs of having been used as a tool. The tool categories recovered during the project were: Utilized Flake, Utilized Core, Trimmed Flake, Shaped Flake, and Biface. Table 3 includes the tool definition and count for each category. Complete lithic proveniences are given in Table 4 .

Eight lithic tools were recovered. They are described below by provenience.

EU 0: A flake (Figure 15a) which has been trimmed along one edge. This edge also exhibits some use-wear.
EU 0: A very small core (Figure 15b). Use-wear is present along one edge, but the raggedness of this edge suggests that the core was not originally intended for direct use, but rather picked up and used as an expedient tool. The frequent use of such small cobbles in Colonial-period sites has been noted (Hard et al. 1995:57).

EU 0: A small flake which has been trimmed along one edge and displays slight use-wear.

EU 0: A small flake with use-wear appearing along one edge.

EU 4: The distal tip of a biface (Figure 16a). The fine pressure flaking and size of the fragment suggest that it is the distal end of a Guerrero projectile point. The Guerrero point is a small, triangular to lanceolate point, with a concave base. The points are usually well made, with very fine parallel flaking (Turner and Hester 1993:216). The Guerrero point is associated almost exclusively with Colonial-period sites in South Texas and Northern Mexico (Hester 1992).

EU 4: A medium-sized utilized flake, with use-wear along one edge.

Table 3. Tool Categories

\begin{tabular}{|c|c|c|}
\hline Count & Description & Tool Definition \\
\hline 2 & Utilized Flake & $\begin{array}{l}\text { Distinct use-wear is present along at least one edge, but there is no } \\
\text { sign of deliberate flaking of the stone. }\end{array}$ \\
\hline 1 & Utilized Core & $\begin{array}{l}\text { At least one edge shows use-wear, but the core does not appear to } \\
\text { be deliberately shaped to be used as a tool. }\end{array}$ \\
\hline 3 & Trimmed Flake & $\begin{array}{l}\text { At least one edge has been methodically flaked, but the overall } \\
\text { shape of the flake has not been affected by the trimming. }\end{array}$ \\
\hline 1 & Shaped Flake & $\begin{array}{l}\text { At least two edges have been flaked, and the overall shape of the } \\
\text { flake has been altered by this trimming. Tools which appear } \\
\text { bifacially worked, but were made on a flake, including projectile } \\
\text { points, are included in this category. }\end{array}$ \\
\hline 1 & Biface & $\begin{array}{l}\text { A bifacially worked artifact, which appears finished and/or has } \\
\text { use-wear along one or more edges. }\end{array}$ \\
\hline
\end{tabular}


Table 4. Recovered Lithics

\begin{tabular}{|c|c|l|c|c|}
\hline \multicolumn{5}{|l|}{ Tools } \\
\hline \multirow{3}{*}{ Provenience } & Level & \multicolumn{1}{|c|}{ Description } & Length (mm) & Width (m m) \\
\hline \multirow{3}{*}{ EU 0 } & Surf.-20 & Trimmed Flake & 39.3 & 31.1 \\
\cline { 2 - 5 } & \multirow{2}{*}{$20-25$} & Core w/ use-wear & 45.8 & 39.1 \\
\cline { 3 - 5 } & & Trimmed Flake & 17.9 & 11.1 \\
\cline { 3 - 5 } & & Utilized Flake & 39.3 & 29.8 \\
\hline EU 2 & $20-25$ & Guerrero Projectile & 30.8 & 12.2 \\
\hline EU 4 & $15-20$ & Distal Biface Tip & 20.4 & 12.6 \\
\hline EU 5 & $15-20$ & Utilized Flake & 47.4 & 34.2 \\
\hline EU 8 & $23-30$ & Trimmed Flake & 11.1 & 8.1 \\
\hline
\end{tabular}

\begin{tabular}{|c|c|c|c|c|}
\hline \multicolumn{5}{|l|}{ Debitage } \\
\hline Provenience & Level & Description & Size Code & Flake Type \\
\hline \multirow{9}{*}{ EU 0} & \multirow{2}{*}{$15-20$} & Flake & 2 & 3 \\
\hline & & Flake & 2 & 1 \\
\hline & \multirow{7}{*}{$20-25$} & Flake & 3 & 3 \\
\hline & & Flake & 4 & 2 \\
\hline & & Flake & 2 & 2 \\
\hline & & Flake & 2 & 2 \\
\hline & & Flake & 2 & 3 \\
\hline & & Flake & 2 & 3 \\
\hline & & Flake & 2 & 1 \\
\hline \multirow{2}{*}{ EU 1} & \multirow{2}{*}{$20-25$} & Flake & 5 & 2 \\
\hline & & Flake & 4 & 2 \\
\hline EU 2 & $16-20$ & Flake & 3 & 3 \\
\hline EU 3 & $20-25$ & Flake & 3 & 2 \\
\hline \multirow{3}{*}{ EU 5} & \multirow{3}{*}{$14-20$} & Flake & 3 & 2 \\
\hline & & Flake & 2 & 3 \\
\hline & & Flake & 2 & 2 \\
\hline \multirow{4}{*}{ EU 7} & \multirow{3}{*}{$26-30$} & Flake & 1 & 3 \\
\hline & & Flake & 2 & 3 \\
\hline & & Flake & 3 & 2 \\
\hline & $30-35$ & Flake & 2 & 2 \\
\hline EU 8 & $22-30$ & Flake & 2 & 3 \\
\hline \multirow{5}{*}{ EU 9} & \multirow{5}{*}{$25-30$} & Flake & 3 & 3 \\
\hline & & Flake & 2 & 3 \\
\hline & & Flake & 2 & 3 \\
\hline & & Flake & 3 & 1 \\
\hline & & Flake & 4 & 2 \\
\hline ST \#3 & $13-24$ & Flake & 2 & 3 \\
\hline
\end{tabular}



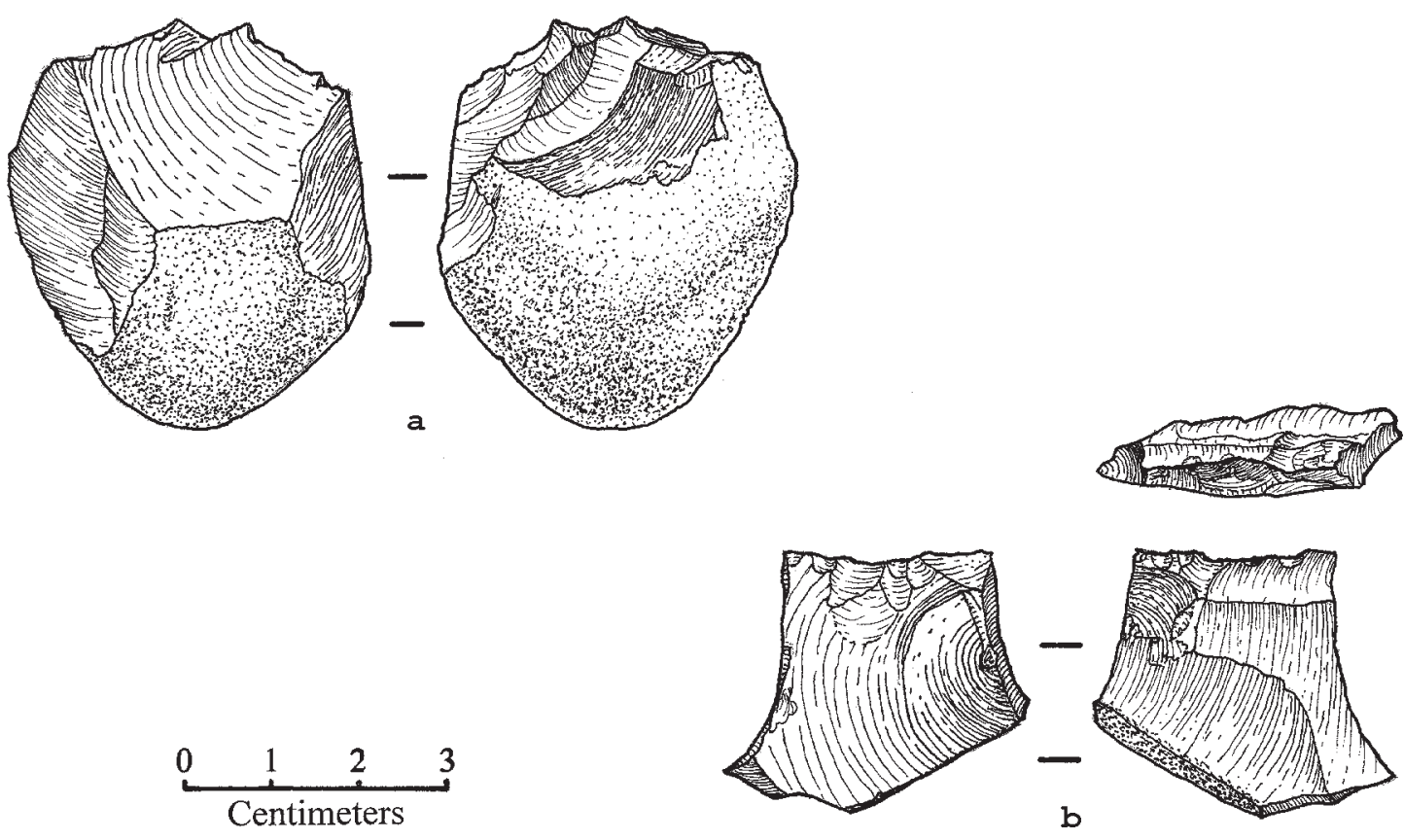

Figure 15. Lithic tools: a. trimmed flake; $b$. small utilized cobble.
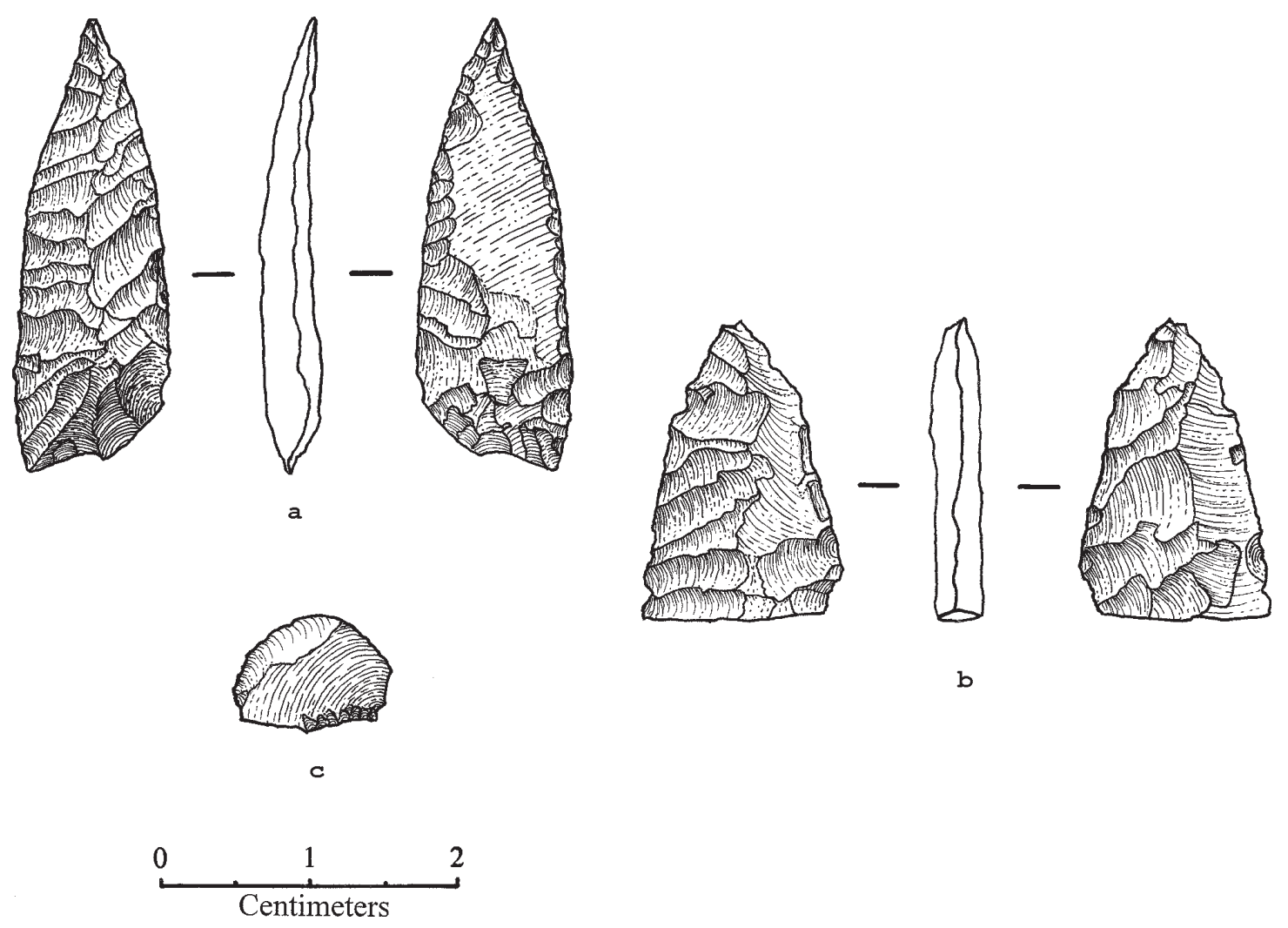

b

Figure 16. Lithic tools: a. distal tip of biface; $b$. Guerrero projectile point; $c$. very small trimmed flake. Note: shown larger than actual size. 
EU 2: A Guerrero projectile point (Figure 16b). The point was clearly made on a flake, but is bifacially finished. It exhibits the typical fine workmanship and parallel flaking of the Guerrero point (Turner and Hester 1993:216). One corner of the base of this point was broken and carefully reworked.

EU 8: A trimmed flake (Figure 16c). This flake is so tiny that it can barely be held by thumb and forefinger. It has been, however, clearly (although almost microscopically) trimmed along the concave curve of one edge. It appears to have been used as a graver for very fine work.

\section{Debitage}

The term debitage is defined here as the by-products of lithic tool production. This term includes flakes, cores, and unfinished tools which were not used as expedient tools. Twenty-seven pieces of lithic debitage, all flakes, were recovered.

Table 5 lists all flakes by type and size. Flake type is one of the most commonly used variables in lithic analysis, although the comparative value is somewhat limited by the fact that the definitions of primary, secondary, and tertiary flakes may vary a great deal from one study to the next (Sullivan and Rozen 1985:757). In this study, the definitions used are: primary, flake has 100 percent of the dorsal surface covered with cortex; secondary, flake has 1-99 percent cortex on dorsal surface; and tertiary, flake has no cortex on dorsal surface. Flake type is used to estimate the stage of lithic production most commonly carried out at the site. That is, a site with a high percentage of primary and secondary flakes but few tertiary flakes is interpreted as a place where only the initial stages of lithic production were carried out, while a high percentage of tertiary flakes indicates that finished tools were being made at the site.

Uecker (1992) provides a comparison of ratios of primary, secondary, and tertiary flakes in several prehistoric and Spanish colonial sites (see Uecker 1992:66, Table 7). This comparison reveals a difference between the two types of sites. Most of the five prehistoric sites cited have a ratio of roughly 5 to 20 to 75 , while the
Table 5. Debitage Flakes, by Type and Size

\begin{tabular}{|c|c|c|c|}
\hline Flake Type & Flake Size & Count & $\%$ of Total \\
\hline \multirow{5}{*}{ Primary } & 1 & 0 & 0.0 \\
\hline & 2 & 2 & 7.4 \\
\hline & 3 & 1 & 3.7 \\
\hline & 4 & 0 & 0.0 \\
\hline & 5 & 0 & 0.0 \\
\hline Total Primary & & 3 & $11.1 \%$ \\
\hline \multirow{5}{*}{ Secondary } & 1 & 0 & 0.0 \\
\hline & 2 & 4 & 14.8 \\
\hline & 3 & 3 & 11.1 \\
\hline & 4 & 3 & 11.1 \\
\hline & 5 & 1 & 3.7 \\
\hline Total Secondary & & 11 & $40.7 \%$ \\
\hline \multirow{5}{*}{ Tertiary } & 1 & 1 & 3.7 \\
\hline & 2 & 9 & 33.3 \\
\hline & 3 & 3 & 11.1 \\
\hline & 4 & 0 & 0.0 \\
\hline & 5 & 0 & 0.0 \\
\hline Total Tertiary & & 13 & $48.1 \%$ \\
\hline Total Flakes & & 27 & $100.0 \%$ \\
\hline
\end{tabular}

mission sites have ratios of roughly 4 to 50 to 46 . Examination of the shaded areas of Table 5 reveals that the ratio of flake types in this collection compares best with the Colonial-period sites in Uecker's table. It also resembles flake type ratios of the lithics recovered during the extensive shovel testing in 1993 (Hard et al. 1995:55, Table 9). It is important to remember, however, that this sample is very small.

Flake size was determined by the smallest circle in which a flake could be completely contained. The circles range in diameter from 1 to $15 \mathrm{~cm}$, and flake size was coded accordingly. The largest flake in this small collection was only flake size 5 , i.e. less than 5 $\mathrm{cm}$ in its longest dimension. The flakes from the 1993 shovel tests were also small, with only 2.31 percent $(\mathrm{n}=3)$ of the total greater than $5.5 \mathrm{~cm}$ in longest dimension (Hard et al. 1995:Table B3). The use of small cores seen at San José in previous excavations (Fox 1979; Greer 1967; Hard et al. 1995; Labadie 1983; Uecker 1992), as well as this project, is probably the reason that the flake size seems to be consistently so small. 


\section{Discussion and Conclusions}

The small size of the lithic collection from the current project precludes intensive analysis. However, it can be noted that the sample closely resembles the lithic material recovered from the 1993 project at the site (Hard et al. 1995). This is not surprising, since these excavations were conducted in parts of the same areas that were tested in 1993.

The sample supports the idea that the Indians continued to make stone tools after becoming part of the mission, that they tended to use small cobbles from the nearby river as their source material, and that they used this material mostly for simple tools, made quickly by a small amount of trimming and shaping or by simply picking up a sharp flake (Hard et al. 1995:57). The exception to the latter observation is the Guerrero point, which is a fine example of a beautifully made bifacial tool. The care with which the Guerrero point was made is reflected in the very fine, at times almost microscopic, flaking seen on even the most expedient of trimmed tools. It appears that good workmanship was important to the mission inhabitants, even for the most expedient tool.

\section{Faunal Analysis}

\section{Johanna M. Hunziker}

A total of 1,709 pieces of bone, weighing 5,390.87 $\mathrm{g}$, was recovered from the excavation units and shovel tests. All the animal bone was identified to the lowest taxonomic level possible using CAR's comparative collection and standard reference guides (Balkwell and Cumbaa 1992; Gilbert 1990; Hillson 1986; Olsen 1964, 1968). Each identified specimen was weighed, and the element, side, remaining portion, and evidence of burning were recorded. Unfused epiphyses were recorded as juvenile, although actual age was only determined for a few specimens. The unidentified mammal-bone fragments were sorted according to size when possible. Size categories were large mammal (cow, bison), medium mammal (deer, goat/sheep, pig, javelina), and small mammal (rodent, rabbit, opossum), or a combination of two sizes such as medium to large mammal.
The bone recovered from the shovel tests consisted of 61 pieces weighing $60.83 \mathrm{~g}$. No further analysis beyond identification, counts, and weights was undertaken on the shovel test assemblage. The bone from the excavation units totaled 1,648 pieces weighing $5,330.04 \mathrm{~g}$. Of this, 206 pieces $(3,063.34 \mathrm{~g})$, or 12.5 percent, were identified to at least the taxonomic level of order, many to genus and species (Table 6). By weight, 57.47 percent of the bone from excavation units was identified.

The most common taxon identified was bovine. Much of the bovine bone was very large and the possibility that it may be bison, given the date of occupation of the site, was considered, although no specimens could be positively identified as bison. The bovine bone that could be positively identified as Bos taurus was recorded as such, and the remaining was recorded as Bovinae, although it probably all cow. All the Bos taurus and Bovinae specimens are considered as a single category in the following discussion. Of the total identified bone from the excavation units, 147 specimens ( 71.4 percent) were cow/bison, which was 92.76 percent of the identified assemblage by weight. Cow/ bison specimens were identified from all excavation units except EU 9. The majority of the bovine bone is made up of lower limb elements such a metapodials, carpels, tarsals, and phalanges. A MNI (minimum number of individuals) of two was determined using second phalanges and the matching pairs method (White 1953).

Two specimens of goat/sheep were identified from EUs 0 and 1 . Goat and sheep are combined into one category due to the difficulty in distinguishing between the two species. The unidentified Artiodactyla specimen from EU 8 compares favorably to goat, but a positive identification could not be made. Other domestic species identified was chicken from EUs 6 and 8, and turkey from EU 0 .

The second-most common species identified was deer. A single specimen from the excavation EU 3 was positively identified as white-tailed deer (an additional specimen from a shovel test was also identified as such). Several deer elements considerably larger than the white-tailed deer from present populations were recorded as Odocoileus sp. These specimens may have 
Table 6. Identified Taxa

\begin{tabular}{|c|c|c|c|}
\hline Taxon & Common Name & Count & $\begin{array}{l}\text { W eight } \\
\text { (grams) }\end{array}$ \\
\hline Bos taurus & cow & 46 & 1311.13 \\
\hline Bovinae & cow/bison & 101 & 1530.49 \\
\hline Capra/Ovis & goat/sheep & 2 & 21.49 \\
\hline Odocoileus sp. & undetermined deer & 6 & 103.94 \\
\hline Odocoileus virginianus & White-tailed deer & 1 & 2.1 \\
\hline Peccari angulatus & Javelina & 1 & 5.28 \\
\hline Artiod actyla & deer/goat/sheep/pig/javelina & 7 & 36.88 \\
\hline Canis latrans & coyote & 2 & 1.57 \\
\hline Canis sp. & unknown canid & 2 & 25.15 \\
\hline Didelphis marsupialis & opossum & 2 & 2.91 \\
\hline Neotoma sp. & woodrat & 4 & 0.60 \\
\hline Sciurus niger & black squirrel & 1 & 0.39 \\
\hline Rodentia & unknown rodent & 2 & 0.72 \\
\hline Lepus sp. & Jack rabbit & 1 & 0.88 \\
\hline Sylvilagus sp. & rabbit & 7 & 2.73 \\
\hline Anser sp. & goose & 1 & 0.80 \\
\hline Anser/Anas & goose/duck & 1 & 0.22 \\
\hline Gallus domesticus & chicken & 2 & 1.73 \\
\hline Meleagris gallopavo & turkey & 2 & 5.48 \\
\hline Centrachid ae & (Black?) bass & 1 & 0.26 \\
\hline Ictalurus sp. & catfish & 1 & 0.36 \\
\hline Colubridae & nonpoisonous snake & 3 & 0.46 \\
\hline Crotalus atrox & Western Diamondback & 2 & 1.67 \\
\hline Crotalus sp. & rattlesnake & 2 & 0.96 \\
\hline Trachemys scripta elegans & Red-eared Pondslider & 1 & 2.22 \\
\hline Testudinata (Emydidae) & box and water turtles & 5 & 2.92 \\
\hline Total & & 206 & 3063.34 \\
\hline
\end{tabular}

been from mule deer, although they were not element portions with characteristics enabling them be to distinguished from white-tailed deer and are probably just very large white-tailed individuals. I have identified several white-tailed individuals as large or larger than modern mule deer from Spanish colonial context at Mission San Juan Capistrano in San Antonio.

The Artiodactyla category includes unidentifiable specimens recovered from EUs $0,2,5$, and 8 that may be deer, goat, or sheep but are too fragmented to be identified below the level of Order. A single javelina specimen was recovered from EU 0. A very fragmented tooth from EU 0 may also be javelina, but it could not be positively identified.

Other wild mammal game species identified include coyote, opossum, jack rabbit, cottontail rabbit, and fox squirrel. Woodrat specimens were identified in addition to other rodent bones which were probably included in the assemblage as a result of natural death, although they may have been used as food items. 
Wild birds identified include goose and a goose/duck recovered from EUs 0 and 8 respectively.

Several reptile remains were recovered, including two families of snake: Western diamondback rattlesnake recovered from EUs 0, 1, and 3, and a nonpoisonous species recovered from EUs 1, 8, and 9. A Red-eared pondslider and possibly one other genus of the box turtle family were identified. Turtle remains were recovered from EUs 0, 2, 5, 7, and 8. Unknown species of catfish and bass were recovered from EUs 0 and 1 respectively.

\section{Bone Modification}

Each specimen was examined for any evidence of modification, such as butchering marks, impact and spiral fractures, burning, and carnivore or rodent gnawing. Butchering marks were identified and recorded as: knife marks, which are thin, relatively shallow cuts; chops, which are deeper, $\mathrm{V}$-shaped marks with some crushing along the edges of the cut as a result of the use of a cleaver or hatchet; and sawcut, either hand sawn or machine sawn. Hand sawing results in striations on the cut surface that are uneven as opposed to the parallel, regular striations left by machine sawing. When the cut surface was too weathered or damaged to determine if it was hand or machine cut it was recorded simply as "sawcut." Only one specimenfrom Level 2 of excavation EU 0 - was positively identified as machine cut.

Forty-three of the cow/bison specimens (29 percent) have butcher marks, with chop marks being the most frequent type of mark $(n=28)$, followed by sawcut $(n=10)$, and knife marks $(n=4)$. Ribs and vertebrae exhibit the greatest number of butcher marks. Sixteen ribs (13 chopped, 2 hand-sawn, 1 knife cut) and 14 vertebrae (10 chopped, 2 hand-sawn, 2 sawcut) account for 69.8 percent of the butcher marks on cow/ bison specimens. Four femur specimens had butcher marks: 3 hand-sawn, 1 both chopped and sawcut. The fourth most common element exhibiting butcher marks was portions of the pelvis, all four marks are chops. Three of the four knife marks occurred on carpals. A cow metacarpal and tibia exhibit spiral fracturing, and a metatarsal has an impact fracture.
Of the cow/bison specimens exhibiting butcher marks, 17 were elements with unfused epiphyses, these included a metatarsal, a tibia, a femur, six vertebrae, and eight undetermined fragments. Based on fusion of post-cranial epiphyses in domestic cattle (Grigson 1982), the metatarsal, tibia, and femur specimens are from individuals less than two to four years in age. The fusion of the vertebral epiphyses varies from three to nine years depending on the particular vertebra (cervical, thoracic, lumbar) which could only be determined for three of the specimens. Two of these were thoracic vertebrae for which fusion of the body epiphyses occurs around eight to nine years (Grigson 1982). The other identifiable vertebra fragment was from a lumbar vertebra for which fusion occurs between two and a half to four years.

Only two other identified specimens showed evidence of butchering marks: one knife mark on a jack rabbit pelvis, and one knife mark on a large unidentified canid vertebra. One deer tibia has a spiral fracture. Of the unidentified bone from the excavation units, 60 pieces had evidence of butchering. Of these, 35 were chopped, 5 were knife cut, 1 was machine sawn, and 19 were hand sawn/sawcut.

The only other type of modification noted was burning on 33 of the unidentified mammal fragments.

\section{Discussion}

Due to the mixture of Colonial with post-Colonial artifacts throughout the units, it is difficult to distinguish the Colonial from post-Colonial bone. The analysis of faunal assemblages from earlier investigations at the mission shows a similar pattern in species identified. The most extensive analyses of these earlier investigations was of material from both outside and inside the original compound (Hard et al. 1995). The faunal material from eighteenth- and nineteenth-century contexts were compared and it was found that the post-Colonial context had a higher frequency of pig and sheep/goat remains and an absence of wild game species. The present assemblage has no pig, and only two specimens of goat/sheep and a diverse assemblage of wild species. Other than five pieces of 
machine-sawn bone the present assemblage appears to contain mostly Colonial-period bone.

The faunal assemblage from the 1993 investigations was very fragmented (Hard et al. 1995). A considerably greater number of bones was recovered $(n=7,066)$ of which only 3.88 percent could be identified to the genus level. The bone from the present assemblage is much more intact. This suggests that the assemblage was discarded in a area with little foot traffic by humans or other animals, and/or was buried soon after discard. There was no evidence of carnivore chewing on any of the specimens, and only one piece was heavily weathered.

The patterning of butcher marks on the bovine specimens was compared to those identified by Scott (1997) on Colonial-period large mammal bones from excavations along the north wall of the Alamo compound. Scott identified "saw cuts ... presumably made with a metal hand saw . . . hack marks . . chop marks defined by $\mathrm{V}$-shaped grooves, made by a meat cleaver or axe ... [and] cut marks . . thin, short lines from knife use" (Scott 1997:57). Scott (1997:57) identified butcher mark patterns as follows, "cut and saw marks were most common on vertebrae and ribs whereas hack marks were encountered in every group of elements. Cut marks and saw marks were the rarest on the long bones" (1997:57).

In Scott's (1997:57) assemblage, the pelvis was "almost always hack-marked." Using modern butchering techniques as a comparison and butcher mark patterns on the Colonial assemblage, Scott suggests a butchering sequence for the Alamo North Wall assemblage that is similar to but slightly modified from that of butchering sequences used during the nineteenth century (Clonts 1983). A summary of Scott's (1997:58) butchering sequence derived for his assemblage from the Alamo is as follows: 1) the removal of the head by sawing or cutting and evisceration; 2) the lower extremities of medium-sized animals (sheep, deer, etc.) were removed by chopping and snapping away the distal tibia and sectioning out the humerusradius/ulna articulation of the forelimbs, for cows the lower limbs were severed at the carpals/tarsals or at the metapodials; 3 ) the limbs were disarticulated from the carcass by hacking, sawing, cutting, or breaking through the scapula above the glenoid fossa, and through the pelvis at the acetabulum; 4) the neck was removed by sawing, then trimmed by cutting or sawing; 5) the meat was removed from the vertebrae and the vertebral column was freed from the ribs by hacking through the transverse processes and the ribs, or the carcass was cut into sections by sawing through the vertebral column.

In Scott's collection, vertebrae and ribs exhibit the highest frequency of butcher marks, as is the case in the present assemblage, and the presence of hack (chop) marks on the pelvis is similar to Scott's observations. A very small faunal assemblage from Mission Espada in San Antonio contained four identified specimens with butcher marks: two chopped cow/bison ribs, one cow/bison metacarpal with an impact fracture, and one goat/sheep pelvis with knife marks (Gross 1998). This assemblage is too small to compare to the 1993 San José or Alamo assemblages, but does support the general trend of location and frequency of butcher mark types seen in the Alamo North Wall and the present assemblages. The number of butcher marks on identifiable bone elements in the present assemblage is too small to adequately establish butchering sequences or to suggest into what portions the carcass was divided beyond the initial removal of the limbs and rib cage. The frequency and placement of the butcher marks supports Scott's modified butchering sequence and is similar to that found from much earlier Spanish sites in sixteenth-century Florida (Reitz and Scarry 1980:85).

\section{Conclusions}

As a result of the present investigation, two sections of the original mission wall footings were exposed and documented. These exterior and interior wall footings indicate that the area reconstructed as the southeast gateway of the mission in the 1930s was actually an enclosed area much like the Indian quarters that occupy the rest of the south wall. These findings confirm our earlier conclusions that "apparently the reconstruction efforts begun in 1935 mistakenly assumed the extant roadway [Mission Road] was associated with a Colonial-period gate where there was none" (Hard et al. 1995). With the agreement of THC, an existing 15-inch gap in these original foundation foot- 
ings was widened to 26 inches to accommodate the installation of the new storm drain.

The installation of numerous utilities and the use of the area as a county road has severely impacted the section between the footings, removing any remnants of the living surface associated with the quarters there. The upper 30 inches of the four excavation units within the enclosure (EUs 6-10) contained Colonial-period ceramic sherds, chert flakes, and faunal remains, along with a sponge-decorated ceramic sherd, window and beer-bottle glass, and wire nails. This mixture was consistent across each unit, indicating a uniform pattern of disturbance in the upper levels. The limited number of artifacts from greater than 30 inches bd (27 inches bs)-four brownware sherds, four pieces of brown glass, two pieces of clear glass, and a small amount of animal bone-was recovered from the trench fill of the water line running along the eastern edge of these units while the remainder of these levels were sterile.

Units EU 0-5 within the mission compound were less uniformly affected by modern disturbances. As expected from the 1993 CAR shovel test results (Hard et al. 1995), the heaviest mixture of Colonial and postColonial-period artifacts occurs in the top 20 inches of deposits. Below this depth, post-Colonial artifacts are limited to the fill associated with intrusive pipe trenches.

The pattern of spatial distribution noted for Colonialperiod ceramics is repeated in the faunal and lithic distributions. The majority (82 percent of count, 94 percent of weight) of the faunal material, 74 percent $(n=28)$ of the lithics, and 78 percent $(n=250)$ of the ceramic sherds from this project were recovered from EUs 0-5 within the compound. Sixty-three percent $(n=201)$ of the total Colonial-periods ceramic assemblage, 63 percent $(n=1,079)$ of the total faunal collection and 53 percent $(n=20)$ of the lithics came from EUs 0-2. These figures indicate a cleared area up to $12 \mathrm{ft}$ wide was maintained in front of the living quarters along this portion of the south wall. This corresponds with the maintained area adjacent to the living quarters along the west wall that was identified during the 1993 CAR investigations (Hard et al. 1995).
Of the 227 non-faunal artifacts recovered from the shovel tests conducted outside the mission compound, 223 are associated with post-Colonial use of the mission (Table 1). The limited number of Colonialperiod artifacts and their mixed context indicates that deposits in this area outside the wall are disturbed. This level of disturbance, however, probably results from the county road construction and twentiethcentury homes along this stretch of property and should not be considered indicative of deposits elsewhere outside the mission compound. The installation of the new storm drain in its presently proposed location will have no impact on Colonialperiod deposits there.

Unfortunately, the prescribed scope of this project and the extent of prior disturbance limit the information we were able to obtain. It is our opinion, however, that a carefully designed investigation within the compound based on information from the 1993 CAR shovel tests (Hard et al. 1994) could supply valuable information about the people who lived inside the walls during the Colonial period. 


\section{References Cited}

Balkwell, D. M., and S. L. Cumbaa

1992 A Guide to the Identification of Postcranial Bones of Bos taurus and Bison bison. Canadian Museum of Nature, Ottawa.

Clark, J. W.

1978 Mission San José y San Miguel de Aguayo: Archeological Investigations, December 1974. Report 29. Office of the State Archeologist, Texas Historical Commission, Austin.

Clark, J. W., and E. R. Prewitt

1979 Archeological Test Excavations in an Area to be Affected by a Proposed Trench Drain West of the Granary: Mission San José State Historic Site (41 BX 3), Bexar County, Texas. Reports of Investigations 3. Prewitt and Associates, Austin.

Clonts, J. B.

1983 Some Long Overdue Thoughts on Faunal Analysis. In Forgotten Places and Things: Archaeological Perspectives on American History, edited by A. E. Ward, pp. 349-354. Center for Anthropological Studies, Albuquerque.

Deagan, K.

1987 Artifacts of the Spanish Colonies of Florida and the Caribbean, 1500-1800. Vol. 1. Ceramics, Glassware, and Beads. Smithsonian Institution, Washington D.C.

Dial, S. W.

1992 Ceramics. In Archaeological Investigations in Alamo Plaza, San Antonio, Bexar County Texas: 1988 and 1989, edited by A. A. Fox, pp. 29-46. Archaeological Survey Report, No. 205. Center for Archaeological Research, The University of Texas at San Antonio.

Fox, A. A.

1988 Archaeological Investigations at Mission Concepción, Fall of 1986. Archaeological Survey Report, No. 172. Center for Archaeological Research, The University of Texas at San Antonio.

1993 Archaeological Testing and Monitoring in Connection with a Drainage Project at Mission San Juan Capistrano, San Antonio, Texas. Archaeological Survey Report, No. 217. Center for Archaeological Research, The University of Texas at San Antonio.

Fox , A. A., and I. W. Cox

1991 Testing the San José Mission Acequia, San Antonio Missions National Historic Park, Bexar County, Texas. Archaeological Survey Report, No. 207. Center for Archaeological Research, The University of Texas at San Antonio.

Fox, A. A., F. A. Bass, and T. R. Hester

1976 The Archaeology and History of Alamo Plaza. Archaeological Survey Report, No. 16. Center for Archaeological Research, The University of Texas at San Antonio.

Fox, D. E.

1970 Archaeological Salvage at Mission San José, December 1969, April and August 1970. Texas Historical Survey Committee, Austin. 
1979 The Lithic Artifacts of the Indians at the Spanish Colonial Missions, San Antonio, Texas. Special Report, No. 8. Center for Archaeological Research, University of Texas at San Antonio.

Gerald, R. E.

1968 Spanish Presidios of the Late Eighteenth Century in Northern New Spain. Museum of New Mexico Research Records No. 7. Museum of New Mexico Press, Santa Fe.

Gilbert, B. M.

1990 Mammalian Osteology. Missouri Archaeological Society, Columbia.

Goggin, J. M.

1968 Spanish Majolica in the New World. Yale University Publications in Anthropology 72. Yale University Press, New Haven.

Greer, J. W.

1967 A Description of the Stratigraphy, Features and Artifacts from an Archaeological Excavation at the Alamo. Report No. 3. State Building Commission Archeological Program, Austin.

Grigson, C.

1982 Sex and Age Determination of Some Bones and Teeth of Domestic Cattle: A Review of the Literature. In Ageing and Sexing Animal Bones from Archaeological Sites, edited by B. Wilson, C. Grigson, and S. Payne, pp. 7-23. BAR British Series 109, Oxford.

Gross, K.

1998 Archaeological Testing of the New Plaza at Mission San Francisco de la Espada (41BX4), San Antonio, Texas. Archaeological Survey Report, No. 262. Center for Archaeological Research, The University of Texas at San Antonio.

Habig, M. A. (compiler)

1978 The San José Papers: The Primary Sources for the History of Mission San José y San Miguel de Aguayo from Its Founding in 1720 to the Present. Part I: 1719-1791. Translated by B. Leutenneger et al. Old Spanish Missions Historical Research Library at Mission San José, San Antonio.

Hafernick, D, and A. A. Fox

1984 Archaeological Testing of Proposed Sewer Line Locations at Mission San José. Archaeological Survey Report, No. 138. Center for Archaeological Research, The University of Texas at San Antonio.

Hard, R. J., A. A. Fox, I. W. Cox, K. J. Gross, B. A. Meissner, G. I. Mendez, C. L. Tennis, and J. E. Zapata 1995 Excavations at Mission San José y San Miguel de Aguayo, San Antonio, Texas. Archaeological Survey Report, No. 218, Center for Archaeological Research, The University of Texas at San Antonio.

Henderson, J., and J. W. Clark

1984 Test Excavations at the Acequia and Other Features at Mission San José, Bexar County, Texas. Publications in Archeology \# 25. Texas State Department of Highway and Public Transportation, Austin.

Hester, T. R.

1992 Indians and Missions in Northern Coahuila and Southern Texas. Paper presented at the Congreso Internacional de Historia, Saltillo, Mexico, May 15, 1992. 
Hillson, S.

1986 Teeth. Cambridge Manuals in Archaeology, Cambridge University Press, Cambridge.

Ivey, J. E., and A. A. Fox

1981 Archaeological Survey and Testing at Rancho de las Cabras, Wilson County, Texas. Archaeological Survey Report, No. 104. Center for Archaeological Research, The University of Texas at San Antonio.

1982 Archaeological Investigations at Mission Concepción and Mission Parkway. Archaeological Survey Report, No. 14. Manuscript on file at the Center for Archaeological Research, The University of Texas at San Antonio.

Ivey, J. E., M. B. Thurber, and S. Escobedo

1990 Of Various Magnificence. The Architectural History of the San Antonio Missions in the Colonial Period and the Nineteenth Century. Volume One. National Park Service Professional Papers No. 11, Santa Fe. Draft on file at the Center for Archaeological Research, The University of Texas at San Antonio.

Labadie, J. H.

1983 Lithic Artifact Analysis from the 1980 and 1981 Seasons at Rancho de las Cabras. In Archaeological Testing at Rancho de Las Cabras, 41WN30, Wilson County, Texas: Second Season, by J. E. Ivey, pp. 47-67. Archaeological Survey Report No. 121. Center for Archaeological Research, The University of Texas at San Antonio.

1964 Mammal Remains From Archaeological Sites, Part 1, Southeastern and Southwestern United States. Papers of the Peabody Museum of Archaeology and Ethnology, Vol. 56, No. 1. Harvard University, Cambridge.

Lister, F. C., and R. H. Lister

1974 Majolica in Colonial Spanish America. Historical Archaeology 8:17-52.

1975 Non-Indian Ceramics from the Mexico City Subway. El Palacio 81:25-48.

Meskill, F. K.

1992 Archaeological Testing Within the Southeast Corner of the Plaza at Mission Espada, San Antonio, Bexar County, Texas. Archaeological Survey Report, No. 208. Center for Archaeological Research, The University of Texas at San Antonio.

Olsen, S. J.

1964 Mammal Remains from Archaeological Sites, Part 1: Southeastern and Southwestern United States. Peabody Museum, Cambridge.

1968 Fish Amphibian and Reptile Remains from Archaeological Sites, Part 1: Southeastern and Southwestern United States. Peabody Museum, Cambridge.

Reitz, E. J., And C. M. Scarry

1980 Reconstructing Historic Subsistence with an Example from Sixteenth-Century Spanish Florida. Special Publication No. 3. Society for Historical Archaeology, Tucson.

Roberson, W., and T. W. Medlin

1976 San José Mission State Historic Site, Archeological Testing 1974 and 1976, edited by I. D. Ing. Archeological Report, No. 23. Texas Parks and Wildlife Department, Historic Sites and Restoration Branch, Austin. 
Schuetz, M. K.

1970 Excavation of a Section of the Acequia Madre in Bexar County, Texas, and Archeological Investigations at Mission San José in April, 1968. Archeological Report 19. Texas Historical Survey Committee, Austin.

Scott, R. F.

1997 Faunal Analysis for the Alamo North Wall Excavations. In Archaeological and Historical Investigations at the Alamo North Wall, San Antonio, Bexar County, Texas. edited by J. E. Ivey and A. A. Fox , pp. 45-60. Archaeological Survey Report, No. 224. Center for Archaeological Research, The University of Texas at San Antonio.

Sullivan, A. P., and K. C. Rozen

1985 Debitage Analysis and Archaeological Interpretation. American Antiquity 50(4):755-779.

Tunnell, C. D.

1966 A Description of Enameled Earthenware from an Archeological Excavation at Mission San Antonio de Valero (the Alamo). Archeological Program Report. State Building Commission, Austin.

Turner, E. S., and T. R. Hester

1993 A Field Guide to Stone Artifacts of Texas Indians. Second edition. Gulf, Houston.

Uecker, H. G.

1992 Lithic Artifacts. In Archaeological Investigations in Alamo Plaza San Antonio, Bexar County, Texas 1988 and 1989. Archaeological Survey Report, No. 205. Center for Archaeological Research, The University of Texas at San Antonio.

White, T. E.

1953 A Method of Calculating the Dietary Percentages of Various Food Animals Utilized by Aboriginal Peoples. American Antiquity 18:396-398. 